\title{
The Effect of Statutory Rape Laws on Teen Birth Rates
}

\author{
By Michael D. FrakeS AND MatTHew C. HARdinG*
}

Policymakers have often been explicit in expanding statutory rape laws to reduce teenage pregnancies and live births by teenage mothers, often with the goal of reducing associated welfare outlays. In this paper, we explore whether expansions in such laws are indeed associated with reductions in teen birth rates. In order to codify statutory-rape-law expansions, we use a national micro-level sample of sexual encounters to simulate the degree to which such encounters generally implicate the relevant laws. By codifying statutory-rape laws in terms of their potential reach into sexual encounters, as opposed to using crude binary treatment variables, this simulation approach facilitates the use of multi-state difference-indifference designs in the face of highly heterogeneous legal structures. Our results suggest that live birth rates for teenage mothers fall by roughly 4.5 percent (or 0.1 percentage points) upon a 1 standard-deviation increase in the share of sexual activity among a given age group that triggers a felony for the elder party to the encounter. This response, however, is highly heterogeneous across ages and weakens notably in the case of the older teen years. Furthermore, we do not find strong results suggesting a further decline in birth rates upon increases in punishment severities.

\footnotetext{
* Associate Professor of Law, Northwestern University School of Law, Faculty Research Fellow, National Bureau of Economic Research, Faculty Fellow, Northwestern Institute for Policy Research, 375 East Chicago Avenue, Chicago, IL 60611 (e-mail: michael.frakes@law.northwestern.edu); Assistant Professor, Duke University, Sanford School of Public Policy, Box 90239, Durham NC 27708-0239 (e-mail: matthew.harding@duke.edu). We would like to thank the following people for their helpful comments: David Abrams, Glenn Cohen, Einer Elhauge, Jonathan Gruber, Michael Heise, Sheri Johnson, Ted Joyce, Mitchel Lasser, Anup Malani, Thomas Miles, Emily Owens, J. J. Prescott, Jeff Rachlinski, Kathy Zeiler and seminar participants at the American Law and Economics Association Annual Meeting, the Robert Wood Johnson Foundation Public Health Law Research Program Annual Meeting, the Cornell Law School Research Colloquium, the Georgetown Law Center Law and Economics Seminar, the Cornell/Tel Aviv University Empirical Legal Studies Conference and the Cornell Law School Summer Faculty Workshop. We are also grateful to the following people for excellent research assistance: Jilian Beck, Chris Chou, Kirill Demtchouk, Kevin Golembiewski, Jennifer Haney, Emilie Jackson, Shirlee Lichtman, Lara Sofia Romero, Stephanie Young, and Jason Zarrow. Finally, we gratefully acknowledge funding for this project from the Robert Wood Johnson Foundation's Public Health Law Research Program.
} 


\section{Introduction}

In 2009 , the teen birth rate in the U.S. was nearly 38 births per 1,000 women between the ages of 15 and 19. This rate is between 2.5 and 7 times larger than those observed in other developed countries (Kearney and Levine 2012). The scale of teenage pregnancies in the U.S. over the years has not gone unnoticed, with numerous commentators and policymakers emphasizing the negative consequences associated with this phenomenon. Whether or not teenage pregnancies constitute a true public health problem itself is a matter of debate in the epidemiological and public health community, with some pointing to the significant negative health outcomes associated with teenage pregnancies-for example, low birthweight and prematurity — and others suggesting that these outcomes are merely the result of related socioeconomic factors (Lawlor and Shaw 2002). What is less debated, however, are the greater economic and educational consequences that likely ensue to teenage mothers (Scally 2002). Moreover, the economic consequences of such births carry beyond the immediate parties themselves, with many state governments over time expressing substantial concern over the toll that teenage live births have taken on welfare expenditures and related outlays (Sutherland 2003). Evidence suggests that, historically, over half of recipients of the Aid to Families with Dependent Children (AFDC) program and its successor, Temporary Assistant for Needy Families (TANF), had their first child while a teenager (GAO 1994, Kaiser Family Foundation 2003).

To address the problems associated with teenage pregnancies, particularly the implications for their welfare rolls, states have been explicit at times in turning to a policy tool that, at first blush, may seem somewhat unusual: criminal law. For instance, with 
congressional encouragement following the welfare reforms inherent in the Personal Responsibility and Work Opportunity Reconciliation Act of 1996 (PRWORA), numerous states set out to ramp up their statutory rape laws-laws that criminalize sexual encounters with partners of particular ages — in an effort to reduce births by teenage mothers and thus reduce their associated welfare expenditures (Sutherland 2003; Donovan 1996). In part animating these efforts were preliminary empirical observations of mean age differences between teenage mothers and the associated fathers of roughly 3 to 4 years, differences that would likely trigger many criminal statutory rape laws. Of course, despite the seeming potential of such laws to forestall sexual encounters leading to pregnancy, there may be many reasons to doubt whether criminalization of such activities would achieve this end. Ultimately, it is unclear whether sexual behavior will actually change in response to fears over statutory rape prosecution. As such, policymakers may have been modifying criminal statutes to address these problems with little to no convincing empirical backing. In this paper, we attempt to address this deficiency and explore whether expansions in statutory rape policies are indeed associated with observed reductions in teenage pregnancies and births by teenage mothers.

Over the years, states have expanded their statutory rape policies across various margins, affording us a rich and robust opportunity to explore the full range of channels by which statutory rape laws may achieve their often stated purpose (though, of course, not sole purpose) of reducing births by teenage mothers. Law and economics scholars often draw on variations along the intensive margins of the law and attempt to identify the influence of criminal forces by exploiting sentence enhancements and other fluctuations in the 
severity of punishment associated with criminal violations. ${ }^{1}$ Such studies have presented a mixed set of findings, casting doubt on the role of punishment scope in tempering criminal behavior (Nagin 1988). In the present study, we do estimate the association between live birth rates by teenage mothers and increases in the punishment severity of statutory rape laws. However, mindful of the generally mixed findings of the punishmentseverity literature, we do not end the inquiry there. Before asking how behaviors change as jurisdictions heighten the scope of imprisonment associated with statutory rape laws, we first ask whether live birth rates fall upon the initial criminalization of those sexual encounters targeted by statutory rape laws. This extensive margin to criminality has been rather underexplored by the empirical criminal law literature to date, perhaps due to the relative rarity in finding variations in the law of the initial-criminalization variety. ${ }^{2}$ The age-specific nature of statutory rape laws, however, affords us the welcome opportunity to draw upon legal variations of this nature and thus to explore the impact of criminalizing activities that were previously permissible-for instance, the impact of expanding the age

\footnotetext{
${ }^{1}$ For example, scholars have evaluated the impacts of punishment enhancements such as capital punishment (Ehrlich 1975; Ehrlich 1977), add-on gun laws (Abrams 2012), three-strikes laws (Helland and Tabarrok 2007), and discontinuous changes in prison length upon the age of majority (Levitt 1998; Lee and McCrary 2009), among many other approaches. For recent surveys on these studies, see Durlauf and Nagin (2010) and Rupp (2008). These surveys generally contend that enhancements in the certainty of punishment are more effective at deterring crime than enhancements in the severity of punishment.

2 Murder will always be criminalized after all, as will robbery and many other types of crime. Those studies that have explored this dimension to the law have done so in arguably less serious contexts (and in contexts that are at least in colloquial terms less "criminal"). Many representative studies have focused on alcohol consumption—for example, alcohol consumption and prohibition (Dills and Miron 2004; Dills, Jacobson and Miron 2005), alcohol consumption and the minimum legal drinking age (Carpenter and Dobkin 2009), and alcohol consumption and Sunday blue laws (Lovenheim and Steefel 2011). Further complicating the ability to study expansions in the scope of criminality of this nature are data limitations. Data on the incidence of particular activities that become criminalized at a particular point of time may only be collected and thus readily available during times following the criminalization of the activity itself.
} 
of consent from 14 years old to 16 years old as Georgia did in 1996. Finally, we supplement these initial-criminalization and sentence-enhancement investigations by evaluating yet another commonly-explored margin to the law: increases in the degree to which criminal infractions are enforced. ${ }^{3}$

Criminal deterrence studies of this variety are often challenged by concerns over measurement error in capturing the underlying behaviors of interest. That is, such studies are often plagued by crime-rate outcomes that suffer from underreporting ${ }^{4}$ or jurisdiction manipulation of crime reports, such as through downgrading of some offenses to lesser crimes to boost appearances (Eterno and Silverman 2012). Our investigation into the impacts of statutory rape laws on teenage pregnancies is arguably robust to such concerns. In addition to illuminating certain public-health and public-finance effects of criminal law, the outcome measure of interest in our analysis - primarily, live birth rates provided by U.S. Natality records_-is necessarily comprehensive and arguably non-manipulable.

This investigation into the impacts of statutory rape laws, however, is not without its challenges, first and foremost of which is the codification of the criminal provisions themselves. Statutory rape laws are multi-faceted along several dimensions, confounding

\footnotetext{
3 Enforcement variations capture fluctuations in the certainty by which punishment is imposed and are often captured through fluctuations in either incarceration rates (Levitt 1996) or police manpower rates (Levitt 1997; McCrary 2002). Two recent surveys of this literature are provided by Durlauf and Nagin (2010) and Rupp (2008). Ultimately, economists and criminologists appear more confident that deterrent forces may be associated with an increase in the probability of detection than with sentence enhancements (Durlauf and Nagin 2010).

${ }^{4}$ Underreporting of crime rates, for instance, may lead to a negative bias in many criminal deterrence contexts, insofar as the error often appears on both the left-hand side and right-hand sides (that is, appearing in the arrest-rate regressor of interest) of the specification (Levitt 1998).
} 
the ability to represent the relevant laws through traditional means-for example, through simple binary treatments of certain features of the law-and thus confounding the ability to draw comparable information from the various expansions in statutory rape policies undertaken by different states. For instance, some expansions may come in the form of a blanket increase in the age by which youths are deemed capable of consenting to sexual intercourse, while other expansions may simply come in the form of narrowing the span in years between the ages of a youth and that of her sexual partner over which intercourse is permissible. On the one hand, treating both expansions as the same will misspecify the breadth of the expansions. On the other hand, only registering the age-of-consent expansion will sacrifice potentially valuable information from the age-gap reduction. Confronting this task is the key methodological contribution we make with this paper.

To codify statutory rape laws, we develop a simulation approach inspired by Currie and Gruber (1996), in which we use micro-level sexual-encounter data (with information on the collective ages of the partners) to generate various measures of the propensity of given states to criminalize sexual activity among given age groups-for example, measures of the percentage of sexual activity generally undertaken by girls of each age that trigger the criminal statutes of the given state and year. ${ }^{5}$ Codifying state laws according to the outcomes of this simulation process allows us to explore expansions in the relevant laws while placing the idiosyncracies of the state-year-age laws and reforms of relevance into a universal and empirically-informed framework, facilitating comparability of the various

\footnotetext{
${ }^{5}$ Other applications of this simulation approach include Gruber \& Yelowitz (1999), Cutler \& Gruber (1996), Deleire et al. (2007), Gruber \& Simon (2008) and Gross and Notowidigo (2011).
} 
reforms. Codification dilemmas of this nature have complicated previous attempts to explore the deterrent impacts of statutory rape laws, specifically, and to explore the impacts of legal structures more broadly.

Using those age-groups that are not impacted by a state's particular reform as a withinstate control-group, we estimate triple-differences specifications bearing on the relationship between the scope and severity of statutory rape laws and the rate of live births among mothers of the targeted ages (with an appropriate backdating of ages and years to reflect gestation length). Our results provide robust evidence suggesting that live birth rates within a particular age group decline upon an increase in the degree to which sexual activity among that age group is initially criminalized; however, our evidence does not conclusively suggest that such birth rates fall further upon the subsequent increase in the degree of punishment. Importantly, we note that these effects appear to be highly heterogeneous across ages, with the findings of a reduction in live birth rates concentrated among the younger ages in our sample. Furthermore, we find that the estimated impact of expansions in the reach of statutory rape laws into previously permissible activities is larger in instances when we would predict that such laws would be more heavily enforced—such as for the youngest age groups-and when we observe markers actually suggesting stronger associated enforcement. Considering the fact that the reduction in live birth rates is only associated with movements into criminality as opposed to increases in punishment lengths, it is arguable that the estimated findings are more reflective of a deterrent rather than an incapacitative impact. 
Of course, the question becomes: what exactly is being deterred? Is the threat of criminal punishment deterring individuals from partaking in the underlying sexual behavior implicated by statutory rape laws? Or, is the threat of criminal punishment simply deterring something more specific - that is, sexual activities that culminate in live births? In other words, are individuals nonetheless continuing with their underlying sexual encounters but responding to the threat of legal action by simply taking measures to avoid detection-in this case, measures that either prevent pregnancy or at least prevent late-stage pregnancy (both of which are likely to alert parents and authority figures to possible statutory rape violations)? The presence of either mechanism may help facilitate the ability of statutory rape laws to achieve their often stated goal of alleviating the problems of live births by teenage mothers; however, only the former mechanism may facilitate the ability of such laws to achieve a broader purpose of deterring the targeted acts of intercourse themselves. We attempt to shed some empirical light on this mechanism question-that is, by ruling out that the documented reduction in live birth rates can be explained by an associated increased in abortions. However, we stress that our investigation along such lines is limited in scope and that our analysis remains focused on the more specific question regarding the link between statutory rape laws and teenage birth rates.

The paper proceeds as follows. In Section 2, we provide a background on statutory rape laws and on their hypothesized impact on teenage sexual activity. In Section 3, we discuss the data and the methodology employed to evaluate expansions in both the reach and the severity of statutory rape laws. In Section 4, we present the results of this analysis. Finally, In Section 5, we conclude. 


\section{Background}

Generally speaking, statutory rape laws implicate criminal liability for the elder member of particular types of sexual encounters depending on the age combinations of the relevant parties. Age restrictions are generally divided into two branches: (1) specified ages of consent and (2) accompanying age-gap triggers. For example, criminal liability may be triggered for an offender (generally, the elder member) to an encounter if the victim is under 16 and the offender is at least 4 years older. Moreover, different types of sexual encounters will trigger different degrees of potential punishment. For instance, an encounter between a 14 year-old and an 18 year-old may trigger a Class C felony statute of a particular jurisdiction while an encounter between a 14 year-old and a 22 year-old may trigger a Class B felony statute of the same jurisdiction.

The threat of criminal liability posed by the presence of a statutory rape law (and by the extent to which it is enforced) may deter potential offenders from deciding to engage in sexual intercourse with partners of prohibited ages. Of course, any such effect presumes that the elder individual is aware of the law and is responsive to this threat. ${ }^{6}$ Even if deterrent forces are strong enough to influence the decisions of the potential offenders, the net effect on sexual activity among the teenage population is ambiguous, itself depending upon the nature of the matching process between sexual partners and thus on the victim's decision-making process (Henry and Cunningham 2010). For instance, consider a given

\footnotetext{
6 Deterrent forces aside, the law may nonetheless have an impact on the distribution of sexual activity through an incapacitation effect to the extent that the imprisonment of offenders renders them unable to perform similar acts in future periods.
} 
15-year-old female whose desired match is a 20-year-old male. Assume that the threat of liability to the male, however, prevents this match from occurring. If the female nonetheless continues searching until she finds another match (with a younger male for instance), she will nonetheless continue to engage in sexual activity. Of course, to the extent that she does not desire the alternative matches to a degree sufficient to expose herself to the added risks, the deterred match with the 20-year old may indeed lead to a reduction in her sexual activity and thus in the likelihood of a negative health outcome. Moreover, given the possibility that older partners are more persuasive in encouraging sexual relations, it may be less likely that the 15 year-old will find an alternative match.

Certain studies have offered insights into the potential impact of statutory rape laws on teenage sexual behavior by exploring the distribution of age differences commonly observed between sexual partners. In one such study, Elo, King and Furstenberg (1999) use data on characteristics of live births to estimate a mean age difference between teenage mothers and associated fathers of over 3 years. Further, turning to data on first-time sexual encounters, they find that roughly half of those who reported initiating sexual activity under the age of 15 did so with a partner who was at least 4 years older. Such studies end the inquiry too soon, however, failing to capture the impact of the law in practice and failing to account for the possibility of blunted deterrence channels.

Attempting to overcome these deficiencies, two additional studies have estimated the observed impact of variations in state statutory rape laws on teenage pregnancy rates and sexual activity. First, Jepsen and Jepsen (2006) estimate a negative association between the presence of a statutory rape law and birthrates for white females using an individual 
sample of teenage females from the June fertility supplements to the Current Population Survey. The authors codify state laws by assigning dummy variables to each individual female in the sample to the extent that they are protected by a rape statute if they engage in sexual intercourse with a hypothetical offender of a given adult age (for example, 21 years old). They impose alternative hypothetical offender ages across separate specifications.

While this multiple-specification approach attempts to account for variations in age-gap structures over time and across jurisdictions, any given specification fails to capture the full and true extent of the variation in state laws, limiting the power of this exercise. For example, assume a state expands the reach of its statutes to implicate all sexual activity among 14 year-olds, whereas it previously allowed sexual activity among this age group if the offender was within 4 years of age. In this instance-which is characteristic of many reforms-an empirical specification that assigns binary statutory rape law indicators according to a hypothetical offender age of 20 years old would register no variation in the law despite a potentially impactful change.

Henry and Cunningham (2010) similarly estimate that an expansion of statutory rape laws is associated with an increased delay in sexual debuts. The authors define state laws by assigning each teen respondent an index variable equal to the span between the respondent's age and the age of a potential partner over which sexual intercourse is permitted-for example, an index value of 9 is assigned if a 14 year old is permitted to have intercourse with partners up to 23 years old. Henry and Cunningham's specification builds on Jepsen and Jepsen's analysis by providing for variations in the possible 
formulations of state laws in a single specification. However, it does so in a relatively parametric and linear fashion. In other words, it implicitly treats the following reforms as having a potentially equal impact on sexual behavior: (1) an expansion to preclude a 22 year-old from having sex with a 14 year-old where the law previously did not trigger criminality until the older party reached 23 years of age and (2) an expansion to preclude an 18 year-old from having sex with a 14-year-old where the law previously did not trigger criminality until the older party reached 19 years of age. However, considering the far greater likelihood that 14 year-olds are engaging in sexual encounters with 18 and 19 yearolds than with 22 and 23 year- olds, the former reform is likely to represent a larger effective expansion in the scope of the law. The methodology considered below expands on this framework by specifying a more natural legal variable that captures the breadth of sexual activity permitted or not permitted for particular ages-that is, the scope of the law-in a manner consistent with the empirical relevancy of the possible offender-victim age combinations.

Our analysis builds on both Jepsen and Jepsen (2006) and Henry and Cunningham (2010) in several additional ways. To begin, our simulation approach facilitates the subsequent evaluation of the impacts of severity enhancements, which were omitted from their analyses and which are difficult to codify through conventional methods (as discussed below). Further, we build on Jepsen and Jepsen by capturing a far greater time horizon of legal variation and by accounting for state fixed effects. We likewise draw upon a greater 
range of legal variation than Henry and Cunningham ${ }^{7}$ and expand upon their analysis by estimating triple-differences specifications that take advantage of the age-specific expansions of the law to account for the possibility of contemporaneous state-year initiatives that likewise target teenage sexual activity. ${ }^{8}$

\section{Data and Methodology}

\subsection{Data}

\subsubsection{Live Birth Rates}

In order to explore whether sexual activity within particular age groups begins to decline as states criminalize a greater range of sexual activity involving those ages, one must track age-specific changes in sexual activity over a long period of time (to capture reforms from the early 1980s to the early 2000s) and across all states. Unfortunately, there is no comprehensive data-source of this nature providing information on the full breadth of

\footnotetext{
7 Henry and Cunningham use the 1979 and 1997 arms of the National Longitudinal Survey of Youth (NLSY), which ask for information on first-time sexual encounters. These data sources effectively prohibit them from taking advantage of the variation in the law in the 1980's. Moreover, their ability to evaluate the rich legal expansions in the mid-1990s is limited. The NLSY in 1997 surveyed a group of 12 to 17 year olds. As such, in evaluating the sexual behavior of youths in 1992 (that is, querying whether they had commenced sexual relations yet), they are only able to observe the behaviors of those 12 and under at that time (representing responses provided by the 12-17 year olds in 1997). This limits the ability to (A) form within state control groups based on older ages at that time and (B) capture variation in the law at that time that targeted older groups. Similarly, in the years following 1997, they are hamstrung in their ability to collect sexual activity data on the younger age groups. For instance, in 1999, they would be unable to collect information on anyone under 14 years of age, considering that the youngest within the longitudinal survey are 14 years old at that time. Ultimately, their approach does not afford rich information on sexual practices at a consistent age-specific level over our time periods of interest.

8 Likewise, these prior studies fail to distinguish between legislative variations representing expansions of the law from those representing contractions, a distinction that may bear on possible attenuation of the results, as discussed below.
} 
sexual activity. However, comprehensive data is available on live birth rates (and slightly less comprehensively on abortion rates) among the relevant populations. Of course, considering the various pathways between sexual encounters and live births, the incidence of teen births may not be the ideal proxy for underlying sexual behaviors. Any documented association between statutory-rape-law expansions and teen birth rates should be interpreted with this caution in mind. Nonetheless, we do embrace such birth rates as our outcome measure of interest in this analysis. Even if they are imperfect proxies for underlying sexual activity, teen birth rates are an outcome of immediate and direct interest to policymakers and have been explicitly invoked as a target of statutory-rape-law expansion efforts (Sutherland 2003; Donovan 1996). In the most specific sense, this paper evaluates the success of these policy efforts.

We collect data on the number of live births associated with each state-year-age cell from the Natality Detail files of the National Vital Statistics System. ${ }^{9}$ Geographic identifiers are not readily available with the Natality Detail records following 2004 and thus we end our sample period in that year. In calculating live birth rates, we count the number of live births born to mothers in each age group between 12 and 17 years old and in each state and year and subsequently divide these counts by the corresponding population. ${ }^{10}$ Of course, to capture a deterrent story, our interest is in exploring how statutory rape laws impact the fact of pregnancy itself. As such, the relevant time period for this analysis is the time of

\footnotetext{
${ }^{9}$ We have collected some limited data at the state-year-age level on the number of abortions reported. This data was collected by the Centers for Disease Control. In the Appendix, we present results of specifications using these alternative measures.

${ }^{10}$ State-year-age population data are from the U.S. Census Bureau and were collected from the National Cancer Institute, a division of the U.S. National Institutes of Health, who compiled these figures for use in calculating cancer and mortality rates.
} 
conception. Accordingly, in allocating live births to state-year-age cells, we use information provided in the Natality records bearing on the length of gestation to estimate the year of conception and the age of the mother at the time of conception. ${ }^{11}$

\subsubsection{Statutory Rape Laws}

We track the evolution of each state's statutory rape laws from 1982 to the present, taking care to observe whether criminal liability is triggered for each potential victim-age / offender-age match-up. ${ }^{12}$ We also track any variation over time in the nature of the associated punishment provisions. This research documents a substantial amount of within-state variation over this time period. With respect to the initial criminalization dimension, roughly 27 states experienced some change in their laws that altered the distribution of sexual activity that triggers a felony in the first instance. The nature of the variation in 17 of these states represented an expansion of criminality into previously

11 After correcting, as stated above, for the estimated time of conception, the average state-year cell in the sample contains roughly 26 live births born to mothers age 12 years old, 123 born to mothers 13 years old, 396 born to mothers 14 years old, 895 born to mothers 15 years old, 1569 born to mothers 16 years old and 2342 born to mothers 17 years old. Live births are extremely rare in the case of mothers 11 years of age and younger. As such, we focus our empirical analysis on the 12-17 year-old age range. However, nearly unchanged results are generated by specifications that nonetheless include 11 year old mothers (available upon request).

12 To track these changes, we observed various sources including current statutory provisions, superceded statute archives, and session law archives. To verify our understanding of the results of such searches, we frequently reviewed case law from the relevant time periods referencing the relevant laws. While our initial goal was to form a 20-year sample and go back to 1985 , we observed a number of states that expanded the scope of their laws in 1985 and thus sought to push the sample back a few more years to take advantage of these variations. Our ability to comprehensively and reliably track the evolution of the relevant statutes became exceedingly more difficult the further back in time our research took us, given certain limitations in the legal data archives. As such, we halted our efforts in the early 1980s. 
permissible activities. ${ }^{13}$ For instance, in 1996, Georgia elevated its age of consent from 14 years old to 16 years old. North Carolina increased its age of consent from 13 to 16 in 1995. Numerous other examples abound. The Appendix provides more information on the nature of these statutory variations. When also incorporating the punishment severity dimension, the vast majority of states experienced some change in their relevant laws over the sample period.

Statutory rape laws take on different forms in different jurisdictions, complicating the ability to place all relevant information in comparable terms and to estimate single specifications that draw upon the experiences of multiple treatment states. However, such differences at least collapse to a manageable number of dimensions: (1) minimum ages of consent, (2) the extent of any gap between the offender and the victim before a violation is triggered, (3) the number of degrees of statutory rape that a state imposes on different offender-victim age combinations and (4) the severity of punishment associated with each statutory degree. The commonalities that nonetheless remain in the structure of statutory rape policies provide us with enough traction to be able to codify and parameterize these laws while still accounting for structural differences.

\subsubsection{Felony/Initial-Criminalization Specifications}

To codify and define the relevant statutory rape laws, we first aim to simulate a measure that captures the proportion of sexual activity among specific age groups that is triggered

13 The remaining 10 states reduced the scope of their laws such that some activities became permissible which had previously triggered felonies. 
by a statutory rape law. The higher the percentage of sexual activity for a particular age that implicates criminal liability for the relevant offender, the more expansive is the specified statutory rape law variable and thus the more likely it may be that the law will curb the incidence of pregnancy. Relative to an approach that simply specifies a binary variable capturing the existence of a statutory rape provision, this specification allows us to take advantage of more variation in the law—for example, that arising from a reduction in the specified age gap. It also allows us to better codify the variation we do observefor instance, to appropriately capture the difference between a state that previously permitted all sexual activity with a 15 year old and that now criminalizes all such activity and a state that likewise newly criminalizes sexual activity with 15 year olds but that nonetheless retains a zone of permissibility if the offender is within three years of age. Presumably, the former state's expansion represents a larger expansion of the law than the latter's.

This approach uses the age distribution of actual sexual encounters to simulate the scope of the laws, thereby assigning different values to the alternative formulations of the law in accordance with their empirical relevancy. For instance, if sex between a 15- and 24-year old is very rare, then the law prohibiting activity only with offenders in the 24-plus range will be given accordingly little weight in a specification that attempts to explain live birth rates among all 15 year-olds.

To obtain a joint offender-victim age distribution for a set of sexual encounters with minors, as required by this simulation approach, we draw on data from the National Survey of Family Growth (NSFG). The NSFG surveys a female population on information 
regarding their first-time sexual encounters, providing details on the ages of both the teen/minor female and her partner in the encounter. While some respondents may be recounting information from a first sexual encounter that occurred years prior, we take an approach similar to that of Elo, King and Furstenberg (1999) and simply view this data as a time-invariant sample of first-time sexual encounters themselves. Despite the possibility that the distribution of the ages of partners of subsequent encounters differ from those of this initial encounter, we can treat this data as a universal proxy for teenage sexual activity - a proxy that is neither year- nor state-specific. With a general sense of what teenage sexual matches look like — for instance, with a sense of how many 15 year olds are engaging in sexual activity with 19 year olds-it is possible to simulate the effective reach of the laws.

More specifically, to form the simulated measures, we begin by taking each observation among the relevant age group in the NSFG and flagging whether the encounter triggers a felony under the laws of the given state and year. We then collapse this information such that we are left with a set of simulated measures of the propensity of the given state and year to extend felony criminal liability to sexual activity within certain age classes_-that is, the percentage of sexual activity among the relevant age group that triggers a felony. This percentage measure serves as the relevant legal measure of interest in the primary specifications. $^{14}$

\footnotetext{
14 This methodology was recently employed by the authors in an evaluation of the deterrent effect of capital punishment eligibility (Frakes and Harding 2009). Representing one of the pioneering applications of this approach, Currie and Gruber (1996) draw on withinstate changes in Medicaid eligibility rules over time to estimate the effect of Medicaid eligibility on healthcare utilization and outcomes. To abstract from individual- and state-specific factors that may be correlated with both utilization and eligibility propensities, they
} 
To simulate an arguably exogenous legal measure, it is preferable to use data on sexual encounters that abstract away from state-specific unobservable factors and that are thus unaffected by the state's laws (Currie and Gruber 1996). For these reasons, we use the national, non-state-specific NSFG records as the baseline for the simulation. As such, the exercise does not necessarily codify the scope of the law by asking what percentage of sexual encounters actually observed within the state trigger a felony within that state. Rather, to focus on capturing the pure structure of law itself, we determine the extent to which the relevant state-year-age law criminalizes sexual encounters within a more universal setting.

\subsubsection{Punishment Severity Specifications}

States often vary their laws not just by moving certain activities into and out of felony status, but also by expanding the potential severity of punishment associated with a given infraction, either by increasing the relevant minimum or the maximum punishment level. The above simulation framework also provides a manageable way to account for variations along the punishment severity dimension. The need for an approach of this nature is perhaps more paramount here. Consider for instance a state that modifies its law by doubling its minimum punishment level from 1 to 2 years for a statutory rape infraction across the board. Now compare this state with another that modifies its law by doubling

instrument individual eligibility with simulated measures of the percentage of children in national samples (within age groups) that are eligible for Medicaid based on the prevailing eligibility rules for the relevant state-year-age group. For a recent example of this Medicaid simulation approach, see Gross and Notowodigdo (2011). 
its minimum punishment level from 1 to 2 years only in the case of a second degree statutory-rape violation, which is triggered only in the relatively rare instance when a person under 14 has sexual relations with someone 24 years of age and older. ${ }^{15}$ The former reform is likely to have a broader impact on sexual activity. By using a sample of sexual encounters to simulate the expected levels of punishment generally implicated by sexual activity among certain age groups, the empirical framework embraced below facilitates comparisons of "apples-to-apples" in capturing the severity of the law.

In our initial approach to codifying severity enhancements, we designate two generic tiers of criminal punishment: (1) the first tier representing the triggering of a basic felony for the associated encounter (that is, incarceration of greater than one year, with a minimum of less than 10 years) and (2) the second tier implicating a heightened felony (that is, a minimum incarceration of at least 10 years). For each state-year-age cell, we then simulate the percentage of sexual activity among the relevant age groups that triggers liability within each of the above tiers according to the laws of the relevant state and year. In yet other specifications, we capture severity expansions by simulating the expected minimum or mean incarceration levels associated with a given sexual encounter among the various age groups. Moreover, in the Appendix, we break the non-parametric approach down into three and four different punishment tiers.

\subsubsection{Descriptive Statistics}

\footnotetext{
15 Limited sentence enhancements of this nature are common in the documented statutory rape law variations.
} 
In Table 1, we provide summary statistics for each of the key variables used in the empirical analysis below, both overall and by age. We document that the typical teenage sexual encounter will trigger a statutory rape felony a significant proportion of the time47 percent of the time to be precise. Keeping in mind the general structure of many statutory rape statutes, this 47 percent finding is consistent with Elo, King and Furstenberg's (1999) own finding of a 3-4 year mean age difference between teenage mothers and the associated fathers and between the age of a girl during her first sexual encounter and the age of her male partner. In other words, given the distribution of ages between sexual partners actually observed, the law at least has the potential to affect a significant number of sexual encounters. As presented in Table 1, this simulated felony incidence percentage falls monotonically from an age-specific high of 82 percent for 12 year olds to 12 percent for 17 year olds.

This 47-percent figure varies considerably over the sample, both across states and withinstates over time. Thirty-two percent of the felony-incidence variation is of the latter variety, reflecting a large amount of inter-temporal legislative changes within states. Take Mississippi for example. The average encounter among 12-17 year olds triggered a felony 12 percent of the time at the beginning of the sample period, a figure that rose to over 50 percent by the end of the sample period as a result of legislative expansions in the mid-1980s and late 1990s.

The incidence of heightened felonies emerges only in the lower age groups, with 12 percent of sexual encounters involving 12 year olds triggering a felony carrying a minimum sentence of 10 years. A given sexual encounter involving 12-17 year-old girls will expect 
to trigger a crime carrying a minimum of 1.3 years of imprisonment (ranging from 3.7 years for encounters with 12 year olds to 0.1 years for encounters with 17 year olds) and a mean (over the possible incarceration range) of 5.7 years of imprisonment (ranging from 13.5 years for encounters with 12 year olds to 0.95 years for encounters with 17 year olds). As such, a given encounter among the youngest age groups is likely to carry more significant consequences. Moreover, in an arena characterized by significant prosecutorial and police discretion, such younger encounters are also more likely to prompt enforcement activity. With this latter idea in mind, we test below for heterogeneous impacts of the law by age, predicting that expansions in the reach of the law will likely be more impactful at younger ages.

\subsection{Empirical Specifications}

To estimate the relationship between teenage birth rates and expansions in the scope and severity of statutory rape laws, we embrace a difference-in-difference-in-difference (DDD or triple-differences) methodology (Gruber 1994). States modified their laws in a staggered fashion over the course of the sample. As a first layer of control, we observe how teen/youth birth rates change in connection with modifications in statutory rape laws, comparing these changes with the associated changes over the corresponding time period within non-modifying states. However, we also take advantage of the age distinctions in the law. When amending their statutory rape laws at a particular point in time, states will generally do so with respect to only one age group, or a subset of age groups. This affords us the opportunity to create another dimension of differentiation through the use of within- 
state control groups. ${ }^{16}$ Nonetheless, we also estimate more basic difference-in-difference (DD) specifications that do not include within-state controls.

By facilitating the inclusion of state-by-year fixed effects, the DDD specification allows us to account for unobservable shocks in particular state-year cells. Among other things, this allows us to control for the influence of unobservable policies and reforms enacted by states over the sample period that likewise have a bearing on teenage pregnancy rates, including, among others, sexual education reforms and sex offender registration and notification laws. Under this DDD approach, the relationship between pregnancy rates and statutory rape laws is identified under an assumption that there are no unobservable stateyear-age factors (including teenage pregnancy-related policies that target specific ages) that are also correlated with the state-year-age statutory rape laws and associated birth rates and that may otherwise be responsible for the estimated findings.

More specifically, we estimate the following specification:

$$
\begin{aligned}
& \text { Ln }\left(\text { Birth_Rate }_{\text {sta }}\right)=\alpha+\boldsymbol{\gamma}_{\mathbf{s}}+\boldsymbol{\lambda}_{\mathbf{t}}+\boldsymbol{\mu}_{\mathbf{a}}+\boldsymbol{\tau}_{\mathbf{s t}}+\boldsymbol{\delta}_{\mathbf{s a}}+\boldsymbol{\rho}_{\mathbf{t a}}+\boldsymbol{\beta}_{\mathbf{1}} \mathbf{L a w}_{\text {sta }} \\
& +\beta_{2} \text { RACE }_{\text {sta }}+\varepsilon_{\text {sta }}
\end{aligned}
$$

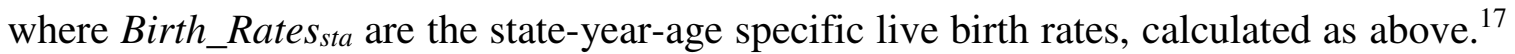
State fixed effects, $\gamma_{\mathrm{s}}$, year fixed effects, $\boldsymbol{\lambda}_{\mathrm{t}}$, and age fixed effects, $\boldsymbol{\mu}_{\mathbf{a}}$, control for fixed

\footnotetext{
${ }^{16}$ For instance, if a state amends its treatment of intercourse with 13 and 14 year-olds but not its treatment of the remaining age
} groups, then the 12-, 15-, 16- and 17-year old age groups within that state may also be employed as control groups for the empirical analysis.

${ }^{17}$ Using the natural $\log$ of the birthrate as the dependent variable would be problematic in the presence of a significant number of zeroes in live birth counts at the state-year-age level. However, out of nearly 7000 cells, only 23 contained zeroes. The results presented below are virtually identical when simply dropping those zero-valued cells through the log transformation of the birth rate or when imposing one live birth in each such cell (the approach taken in the analysis below). Moreover, the general results presented below are 
differences across states, years and specific age groups, respectively. The inclusion of $\boldsymbol{\tau}_{\mathbf{s t}}$, $\boldsymbol{\delta}_{\text {sa }}, \boldsymbol{\rho}_{\text {t,a }}$ provides for fixed differences across different state-year groups, state-age groups and year-age groups respectively. The percentage of the state-year-age female population that is black is captured by $R A C E_{\text {sta }}$ (representing the one demographic variable we have available at the state-year-age level over this time period). The various alternative specifications of the statutory rape law variable discussed above are captured by Lawsta. The coefficient of interest is represented by $\boldsymbol{\beta} \mathbf{1}$, reflecting the relationship between live birth rates and expansions in the scope or severity of statutory rape laws. Negative values of this coefficient are suggestive of a deterrent and/or incapacitative effect of statutory rape provisions.

This DDD specification implicitly expects age-specific responses to certain statutory rape law modifications. With respect to the incapacitation channel, if repeat offenders of statutory rape violations are inclined to target the same age groups again, then an agespecific reform could indeed be expected to result in an age-specific decline in sexual activity. With respect to the deterrence channel, the DDD specification requires certain assumptions regarding potential offenders' awareness of the changing legal environment. For instance, consider a reform that targets only one age group. To result in an age-specific deterrent response, potential offenders must arguably be made aware that the laws regarding the targeted age group were altered while those regarding the other ages were not. Of course, it could be the case that some potential offenders only target partners of

robust to the alternative estimation of Poisson specifications that deal with zero values more directly, as discussed below and as discussed more thoroughly in the Appendix. 
particular ages, in which case all that may be required to observe a deterrent response is that those offenders become aware of changing legal expectations for the types of sexual encounters they are otherwise interested in pursuing.

Law awareness questions of this nature arise frequently in deterrence contexts. At least in comparison with other types of serious crime (such as murder and robbery), statutory rape laws implicate a general activity in which a substantial percentage of the population partakes: the matching process of finding a sexual partner. It is perhaps plausible to believe that at least a portion of this population may be aware of relevant changes in this legal landscape, especially an increase in the age of consent. Sutherland (2003) supports this general law-awareness expectation in the statutory rape context through a number of observations including the long-term maintenance of the slang-term "jailbait." In any event, the results below are nearly identical when estimating more basic difference-indifference specifications, which require weaker knowledge-related assumptions.

\section{Results}

\subsection{Felony / Initial Criminalization Specifications}

In Table 2, we present results of the felony-incidence specifications, which bear on the impacts of initially criminalizing a greater portion of sexual encounters. More specifically, the specifications estimated in Table 2 codify an expansion in statutory rape laws according to the percentage of sexual activity among girls of each age that trigger a felony according 
to the laws associated with the relevant state-year-age cell. ${ }^{18}$ In our primary specifications reported in Panel A, we focus on variations in the law of an expansionary nature onlythat is, we only draw upon instances in which states expand upon the breadth of sexual activity that triggers a felony (including an increase in the age of consent or a decrease in the relevant age gap), as opposed to instances in which states also cut back on this breadth. The primary concern with drawing upon a contraction in the law is that the legislature may have simply codified a pre-existing disposition on the part of the state not to prosecute the previously implicated activities. For instance, if prosecutors had previously elected not to pursue offenders within several years of age of the victim, then the imposition of a 3-year age gap provision by the legislature may not be expected to alter the deterrence landscape, potentially attenuating the results towards zero. ${ }^{19}$ Nonetheless, we likewise estimate specifications that embrace both expansions and contractions in the law.

We begin in Column 1 of Table 2 with a basic difference-in-difference specification that includes only state, age and year fixed effects and that specifies the dependent variable as the $\log$ of the relevant state-year-age birth rate (dated at the time of conception). With the dependent variable specified as such, the estimated coefficient suggests an 11.5 percent reduction in live birth rates associated with an increase from 0 to 100 percent in the degree

\footnotetext{
${ }^{18}$ Each observation in the specifications estimated throughout Section 4 is weighted by the state-year-age population count used to
} form the denominator in the birthrate variable. Moreover, the coefficients estimated in each table are multiplied by 100 , facilitating an interpretation of the findings as a percentage change in the relevant live birth rate. Standard errors are clustered at the state level to allow for arbitrary within-state correlations of the error structure-that is, within-state auto-correlation in age-specific residuals and/or within-state auto-correlation in cohort-specific residuals.

${ }^{19}$ For this reason, the expansion-only specification was overwhelmingly the preferred specification by criminal law scholars that we spoke with concerning this analysis. 
to which sexual activity among a given age group triggers a felony for the elder party to the encounter. Considering a mean live birth rate of 2.5 percent over the sample, this estimate represents a 0.3 percentage-point reduction in the live birth rates for a given stateyear-age cell. In terms of a one standard deviation increase in the simulated felony incidence variable — as opposed to a 100 percentage point increase in the felony variablethis estimate suggests a 5.4 percent reduction in live birth rates (or a 0.1 percentage point reduction). As demonstrated by Column 2, this estimate changes only slightly from -11.5 to -10.7 with the inclusion of various state-year controls bearing on the prevailing economic and social environment. ${ }^{20}$ Controlling flexibly for a greater range of timevarying state-specific factors and taking advantage of the within-state control groups afforded by the age-specific expansions in the law, we next find that this estimated coefficient remains nearly unchanged at -12.5 with the inclusion of state-year fixed effects (Column 3).

This latter finding suggests that omitted state-year initiatives and policy reforms likewise bearing on teenage pregnancy rates may have not necessarily confounded the basic difference-in-difference findings and thus suggests that state-year expansions in statutory rape laws are perhaps close to random in nature. Nonetheless, to also control flexibly for omitted age-year, and state-age effects, we estimate the full triple-differences specification (Column 4), finding a 13 percent reduction in live birth rates in association with an increase

\footnotetext{
${ }^{20}$ Such controls include unemployment rate, percentage black, percentage living in urban areas, median household income, and the prevailing violent-crime offense rate. State-year unemployment rates are from the U.S. Bureau of Labor Statistics. Demographic measures and percent urbanization are from decennial Census files (1969-1999) and American Community Surveys (ACS) (2000-2004). Criminal offense data is from the Federal Bureau of Investigation's Uniform Crime Reports.
} 
from 0 to 100 percent in the simulated felony incidence rate. While few covariates are available at the state-year-age level over this time period, we do confirm that these estimates remain virtually unchanged with the inclusion of a control for the percentage of the state-year-age population that is black (Column 5). ${ }^{21}$ Moreover, as discussed in greater detail in the Appendix, we confirm that the statistical significance of these findings likewise holds under an alternative randomization inference approach.

The basic identifying assumption of the triple-differences specification is that there are no unobserved factors specific to given state-year-age groups that are correlated with the state-year-age-specific expansions in statutory rape laws. As an additional specification check, we challenge this identifying assumption by imposing state-age-specific linear time trends (for example, a unique time trend associated with 12 year olds in Iowa), allowing us to control for slowly-moving unobservable factors that may be correlated with both stateage-specific pregnancy rates and state-age-specific laws. This inclusion suggests a slight intensification of the estimated association of interest (Column 6).

To rule out concerns that these results are merely reflective of pre-existing differential trends between the treatment and controls groups, as opposed to being reflective of a true policy response, we also estimate specifications that include 2- and 4-year leads of the

${ }^{21}$ When systematically dropping each state one-by-one from the estimation sample, the primary triple-differences coefficient from Column 3 (with our baseline of comparison equal to -13) remains in roughly the same range, from a low (in terms of an implied deterrence impact) of -8.9 when dropping Pennsylvania to a high of -16.0 when dropping Nevada. While the felony incidence variable benefits from an empirically-informed depiction of the potential reach of the law, it nonetheless operates in a relatively parametric fashion in the above specification. In Table A2 of the Appendix, we present results from a more non-parametric approach, where, rather than treating the simulated felony incidence variable linearly, we divide the felony incidence variable into four quartiles and estimate the association between live birth rates and the incidence of moving into a higher quartile. 
simulated felony-incidence variable (Column 7). ${ }^{22}$ The estimated coefficients of these lead variables are nearly 0 in magnitude and statistically indistinguishable from 0 (moreover, while the F-statistics are not provided, they are likewise jointly indistinguishable from 0 ). In Column 8, we estimate an even more dynamic specification by including 2- and 4- year lag variables, ${ }^{23}$ allowing us to test for any delayed responses to the change in the criminal law environment. The negative association of interest appears to occur predominantly in the 2-year period following the enactment of the law change.

Finally, in Panel B of Table 2, we include variations in state statutory rape laws that incorporate both expansions and contractions in the law. Consistent with our expectations that contractions in the law may merely reflect previous dispositions of the state not to prosecute the now officially permissible behavior, this inclusion appears to attenuate the results slightly towards zero. The estimated coefficient of the felony-incidence variable falls (in absolute value) to -10.6 , though nonetheless remains statistically significant.

In this primary approach to exploring the relationship between teenage pregnancies and expansions in the scope of statutory rape laws, we estimate least squares (OLS) regression specifications and use live birth rates (per population) as the dependent variable. In alternative specifications, we explore this relationship using Poisson regressions (with an

\footnotetext{
22 These variables indicate at time $t$ a state-age group's simulated felony percentage at times $t+2$ and $t+4$, respectively. As such, if a state-age group's simulated felony percentage increases from 0.25 to 0.5 in 1995 , the 2 -year lead of this variable will register this switch in 1993. Pre-period trends could signal such things as mean reversion, legislative endogeneity or other omitted factors of concern.

23 These variables indicate at time $t$ a state-age group's simulated felony percentage at times $t-2$ and $t-4$, respectively. As such, if a state-age group's simulated felony percentage increases from 0.25 to 0.5 in 1995, the 2-year lag of this variable will register this switch in 1997.
} 
exposure offset based on the relevant population). In the Appendix, we discuss and demonstrate the general robustness of the OLS results to this alternative count-based specification. $^{24}$

\subsection{Felony Incidence and Sentence Enhancement Specifications}

Having addressed the deterrent impacts associated with initially criminalizing a broader range of sexual activity, we now explore the subsequent impacts of sentence severity enhancements. We begin in Table 3 by estimating specifications that include measures simulating both the percentage of sexual encounters triggering a basic felony statute and the percentage of such encounters triggering a heightened felony (as specified above). Each column of Table 3 follows the associated specification from Table 2. For instance, in Column 4, we estimate the full triple-differences specification, finding a similarly-sized reduction in live birth rates of roughly 15 percent (or roughly 0.3 percentage points) in connection with an increase from 0 to 100 percent in the basic simulated felony incidence. The basic-felony coefficients from the remaining specifications closely follow those

\footnotetext{
24 The analysis is aggregated enough in time and geography—-that is, year and state—-that the rare-event rationale for a count model is perhaps less relevant. With an average of roughly 890 live births in each state-year-age cell, there is little general concern of censoring at zero that could lead to a skewed error distribution at this lower bound. Moreover, with only 23 instances of 0 -valued cells out of nearly 7000 state-year-age cells, there is little interference with the ability to log transform the birthrate dependent variable to deal with general skewness in the error distribution and better achieve normality. Moreover, with an average female population size per stateyear-age cell of roughly 37,000 , the estimated birth rates need not be viewed as so discrete in nature and may be sufficiently continuous to warrant least squares estimation (Osgood 2000). This is arguably true even in the case of the younger ages within the sample, where live birth counts per cell are more modest but where female population counts—-that is, the denominator-are nonetheless sufficiently large to generate continuity in the calculated birthrates. Ultimately, for these reasons, we elect to estimate OLS specifications as our primary approach. Nonetheless, as a robustness exercise, the Appendix estimates Poisson specifications.
} 
estimated in Table 2. However, we estimate only a 2 percent subsequent reduction (statistically insignificant) in live birth rates in connection with an increase from 0 to 100 percent in the incidence of a heightened felony (Column 4).

Of course, these basic/heightened-felony specifications fail to capture much of the finegrained variation in the severity dimension of the law. In Table A4 of the Appendix, we estimate specifications that include three and four punishment bins. The estimated coefficients of the basic felony incidence variable in these alternative specifications remain nearly identical to those presented in Tables 2 and 3, while the coefficients of the variables capturing the percentage of sexual activity falling into the heightened punishment tiers are closer to zero in magnitude and statistically indistinguishable from zero. Overall, the results continue to demonstrate that the documented association between live birth rates and expansions in the scope in statutory rape laws appear to be substantial in the initial movements into criminalization; however, our results do not leave us with a strong inference of a similar impact in connection with severity enhancements.

The specifications estimated in Tables 3 and A4 benefit from a relatively non-parametric treatment of incarceration length associated with infractions of statutory rape laws. However, the coarse classifications still do not capture the full extent of the documented variations. For instance, they do not capture increases in minimum sentence lengths from 1 to 2 years or increases in the potential range of permissible incarcerations due, for instance, to an extension in the maximum punishment. In Table 4, we attempt to fill these gaps and codify punishment severity by simulating the expected minimum (Columns 1-3) or mean (Columns 4-6) incarceration length associated with a given sexual encounter 
among the relevant age group (where the mean is based on the potential punishment range). In Columns 2-3 and 5-6, we likewise include a measure of the simulated felony incidence, allowing us to simultaneously estimate the extensive and intensive dimensions of the lawi.e., the initial-felonization margin and the sentence enhancement margin. The estimated coefficients of the simulated felony-incidence variables are consistent in magnitude and precision with those estimated in Tables 2 and 3. Moreover, the estimated coefficients of both the expected minimum and mean incarceration variables are consistent with the heightened-felony incidence variables from Tables 3 and A4 in failing to demonstrate that sentence enhancements may be associated with further reductions in live birth rates. For instance, as presented in Column 2, we estimate that an increase of 1 year in the expected minimum punishment levels_-representing a roughly 69 percent increase over a mean of 1.45 years - is associated with a modest and statistically-insignificant 0.3 percent increase in live birth rates (or a 0.007 percentage point increase).

\subsection{Enforcement; Rationality Exercises}

\subsubsection{Enforcement Effects}

One important aspect of the law not emphasized in the above analysis bears on its enforcement. A technical violation of the law may only lead to actual consequences for the actor to the extent that the police force and prosecutors pursue the offending party. One may be concerned that expansions in the statutory scope or severity of the law as it applies to teenagers as a whole are accompanied by increases in the degree to which the state generally enforces its statutory rape provisions (both with respect to its existing provisions 
and to any new provisions), jeopardizing identification of the impacts of scope and severity expansions. However, to the extent that enforcement initiatives are not enacted in an agespecific manner within states, the triple-differences specification is designed to rule out concerns of this nature and better target the expanded scope of the law. To the extent that variations in enforcement efforts within states occur on a victim-age-specific basis, this targeting becomes more difficult given the lack of enforcement-related data over the sample period at the state-year-age level. ${ }^{25}$

Nonetheless, to shed some light on the isolated effects of enforcement initiatives with the data that is available, we estimate difference-in-difference specifications at the stateyear level building on Column 1 of Table 2 that include state-year arrest rates for nonforcible rape sex offenses (which include statutory rape offenses). We present the results of this exercise in Table 5. In Column 1, we find that a 1-standard-deviation increase in the arrest rate of 18-30 year old males is associated with a roughly 3.3 percent reduction in live birth rates. ${ }^{26}$ The estimated coefficient of the felony-incidence variable in this specification is nearly identical to that estimated in Table 2, suggesting little concern that our main difference-in-difference findings is merely reflective of correlated enforcement initiatives.

\footnotetext{
25 Limited information may be available under the National Incident-Based Reporting System, however only for a limited number of years and a limited number of states, jeopardizing the ability to simultaneously estimate a triple-differences specification drawing on variations in the scope of statutory rape laws.

26 These findings remain essentially identical when using 18-40 year old male arrest rates or 18-plus male arrest rates. The specification controls for forcible-rape arrest rates to account for other sex-offense enforcement efforts more broadly.
} 
As a rationality check on our main findings above, we take further advantage of the availability of state-year arrest rates for non-forcible rape sex offenses to test the prediction that the triple-differences coefficient from the initial-criminalization analysis is more pronounced when accompanied by a criminal justice system that is inclined to pursue offenders of non-forcible rape sex offenses relative to one that is not so inclined. ${ }^{27}$ To test this prediction, we estimate specifications that modify that estimated in Column 3 of Table 2 (the main triple-differences specification) to include an interaction between the stateyear-age felony-incidence variable and the state-year arrest rate for non-forcible rape sex crimes (see Column 2 of Table 5). ${ }^{28}$ As predicted, we estimate a negative value of the coefficient of the interaction term suggesting a stronger response (that is, a heightened negative response) to the law when met by an environment that is more inclined to pursue associated violations. ${ }^{29}$

\subsubsection{Differential enforcement and heterogeneous treatment effects}

One would imagine that a given infraction of a statutory rape law is more likely to be enforced when the victim is on the younger end of the spectrum considered by our analysis.

\footnotetext{
27 A related prediction is that an increase in enforcement proclivities will have a greater impact on the incidence of sexual activities in those jurisdictions that have a broader reach of the law (that is, a higher simulated felony-incidence value) relative to those with a more limited reach.

${ }^{28}$ Of course, we likewise include the necessary constitutive term - that is, the state-year arrest rate for non-forcible rape sex offenses. Likewise, to control for forcible rape enforcement efforts, we include forcible rape sex offense rates, along with the interaction between those rates and the felony-incidence variable.

${ }^{29}$ Future research in this area might benefit from similar interactions between the scope of statutory rape laws and various enforcement-focused initiatives, including laws requiring physicians and various public officials to notify authorities upon learning of instances of statutory rape violations, in addition to similar notification laws-e.g., parental notification laws in the abortion context.
} 
As such, one might predict that the impact on teenage birth rates felt from initially criminalizing sexual activity, in light of these likely enforcement differentials, will be more pronounced for younger age groups. As such, in Table 6, we present regression results whereby we test for heterogeneous responses to expansions in the scope of statutory rape laws across the different age groups (by interacting the state-year-age felony incidence variable with indicator variables for each of the various age groups, omitting the 17-year old group as the reference category). Consistent with these expectations, we indeed find that the association between the simulated felony-incidence variable and live birth rates is the most strongly negative among 12 year olds and becomes less negative (or more positive) as age increases monotonically, suggesting that the deterrent impact of statutory rape laws weakens with age, as expected. More specifically, adding the first two rows in this table suggests that as we move from 0 to 100 percent felonization of sexual activity with 12 year olds, we observe a roughly 20 percent decline in the live birth rate of 12-year olds, or roughly a 0.01 percentage-point decline in the 12 -year-old live birth rate. This effect falls in magnitude until it turns positive for 15 year olds. The average effects estimated in Table 2 remain negative, in part due to the fact that most of the legal amendments exploited for this analysis are targeted at the lower ages.

While providing a rationality check in complying with expectations regarding which ages are more likely to face stronger enforcement, these findings of heterogeneity in treatment across ages do suggest caution in interpreting the average findings from Table 2. Increasing the scope of statutory rape laws may not lead to a reduction in live birth rates in the case of youths 15 years of age and above. 
Finally, in the Appendix, we also test for heterogeneity in treatment effects across races. Much has been said in the statutory rape law literature about the extent to which the enforcement of the law has been levied in a very highly disproportionate manner against black or Hispanic males (Sutherland 2003), supporting a prediction that the expansion in the scope of statutory rape provisions into new ranges of sexual activity will have a stronger impact on associated lived birth rates among the minority population. ${ }^{30}$ We present evidence in the Appendix supportive of this prediction, consistent with the above rationality checks suggesting stronger treatment effects in settings in which we either know of stronger enforcement or would predict stronger enforcement.

\section{Discussion and Conclusion}

The empirical literature in crime has long endeavored to explore the impact of criminal law on the incidence of those activities implicated by criminal statutes. This exercise has faced numerous obstacles, beginning with the difficulties associated with identifying the channel or mechanism behind any observed response. Mainly, are the observed reductions in crime attributable to deterred behavior on the part of would-be offenders or are they attributable to incapacitating previous offenders from repeating their past activities? The present study is not necessarily designed to confront this deterrence-versus-incapacitation question, and, instead, aims to solidify our understanding of the more basic specific

\footnotetext{
30 As discussed further in the Appendix, this heightened enforcement targeted at black and Hispanic males does not arise simply from situations in which they have intercourse with white females. Prosecutions also arise frequently from situations in which black or Hispanic females become pregnant as a result of such encounters (Sutherland 2003).
} 
question: do statutory rape laws reduce teen birth rates? That being said, it is perhaps reasonable to believe that a deterrent response is behind at least some of the reduction in live birth rates that is found to be associated with the criminalization of sexual encounters (to the offending party at least) involving that age group. After all, if incapacitative forces had a large impact on live birth rates, one would presumably expect to observe a response along the punishment severity dimension. The above findings, instead, appear to be concentrated on initial movements into criminalization. ${ }^{31}$

Even assuming a deterrent, as opposed to an incapacitative, framework, additional mechanism questions arise. Precisely what behavior is being deterred? Consider the present context. Expansions in statutory rape laws are found to be associated with reductions in live birth rates. However, is this attributable to an actual reduction in sexual activity? Or has the underlying incidence of sexual activity remain unchanged and have we simply seen an increase in measures such as contraception taken to avoid pregnancies or an increase in measures such as abortions taken to avoid live births? Parties may respond to statutory-rape-law expansions in these latter manners in an attempt to circumvent detection of a statutory rape violation (at least to serve the interests of the elder partner).

\footnotetext{
${ }^{31}$ Some may question the ability for statutory rape laws to deter given the law rates of enforcement likely to operate in this context. After all, only 0.2 percent of males aged 18-30 are arrested on average in a given year for non-forcible sex offenses (which includes statutory rape offenses). However, a dampened deterrence channel need not occur in the fact of light enforcement if the consequences associated with statutory rape violations are considerable enough (Becker 1968). In a crime of this nature, more is certainly at stake than simply imprisonment. Relative to some serious crimes, a greater degree of social humiliation may follow incarceration for the commission of a sex offense against a minor. This social stigma channel is perhaps of more significance since the 1990s, following the move across jurisdictions, precipitated by two federal mandates, to require sex offenders to register with, and provide personally identifiable information to, law enforcement agencies and subsequently mandate that this information be made available to the public (Prescott and Rockoff 2011).
} 
Premised behind this response is the idea that the fact of a late-stage pregnancy or a live birth itself may signal to authority figures or parents that a possible statutory rape violation has occurred.

In Table A8 of the Appendix, we present evidence suggesting that the observed reduction in live birth rates cannot likely be explained by a corresponding increase in abortion rates, as would be predicted by this circumvent-detection mechanism, suggesting that the response observed above may indeed be a reflection of reduced sexual activity itself. With richer data on contraception use across states and time (and ideally across ages), future research might hopefully shed light on a possible contraception circumvention mechanism. ${ }^{32}$ Evidence of either reduced underlying sex or increased live-birth-avoidance measures would be consistent with a responsiveness in behavior to the prevailing criminal law environment - that is, evidence of deterrence of some nature, whether of underlying sexual encounters or of sexual encounters that culminate in live births. However, it may be worthwhile to identify the precise nature of deterrence in order to determine whether the goals of statutory rape law have been satisfied. Of course, those goals themselves are multi-faceted. While many normative theories of statutory rape likely aim at curbing the underlying sexual activity itself, policymakers, as discussed at the outset, have often looked

\footnotetext{
32 In future research, we also hope to extend this methodological framework to data sources providing more direct information on underlying sexual practices, thus more directly addressing this concern. For instance, we hope to acquire geographic identifier codes within the NSFG records facilitating the ability to construct similar DD and DDD analyses in questioning the impact of statutory rape expansions on the onset of sexual debuts. The NLSY records considered by Henry and Cunningham (2010) also afford this opportunity. However, for the reasons identified above, the NLSY is likely to be limited in the extent of legislative variations it is able to accommodate.
} 
upon such laws as tools to battle live births by teenage mothers as a specific outcome. At the least, the results of this analysis are suggestive that such live birth rates may indeed decline — at least in the case of those youths fourteen years old and younger—subsequent to expansions in the scope / reach of statutory rape law and in the degree to which they are enforced.

\section{References}

Abrams, David S. 2012. "Estimating the Deterrent Effect of Incarceration Using Sentence Enhancements." American Economic Journal: Applied Economics 4(4): 32-56.

Becker, Gary. 1968. "Crime and Punishment: An Economic Approach." The Journal of Political Economy 76: 169-217.

Bertrand, Marianne, Esther Duflo, and Sendhil Mullainathan. 2004. "How Much Should We Trust Differences-in-Differences Estimates?" Quarterly Journal of Economics, 119(1): 249-75.

Carpenter, Christopher, and Carlos Dobkin. 2009. "The Effect of Alcohol Consumption on Mortality: Regression Discontinuity Evidence from the Minimum Drinking Age." American Economic Journal: Applied Economics 1(1): 164-82. 
Conley, Timothy, and Christopher Taber. 2011. "Inference with 'Difference-inDifferences' with a Small Number of Policy Changes." The Review of Economics and Statistics 1, 113-25.

Currie, Janet, and Jonathan Gruber. 1996. "Health Insurance Eligibility, Utilization of Medical Care, and Child Health.” Quarterly Journal of Economics 111: 431-66.

Cutler, David and Jonathan Gruber. 1996. "Does Public Insurance Crowd Out Private Insurance." Quarterly Journal of Economics 111 (2): 391-430.

DeLeire, Thomas, Leonard Lopoo, and Kosali Simon. 2007. "Medicaid expansions and fertility in the United States.” Working Paper 12907, National Bureau of Economic Research.

Dills, Angela K., and Jeffrey A. Miron. 2004. "Alcohol Prohibition and Cirrhosis." American Law and Economics Review 6(2): 285-318.

Dills, Angela K., Mireille Jacobson, and Jeffrey A. Miron. 2005. “The Effect of Alcohol Prohibition on Alcohol Consumption: Evidence from Drunkenness Arrests." Economics Letters 86(2):279-294.

Donovan, Patricia. 1996. "Can Statutory Rape Laws be Effective in Preventing Adolescent Pregnancies?" Family Planning Perspectives 29(1): 30-40.

Doob, Anthony M., and Cheryl Webster. 2003. "Sentence Severity and Crime: Accepting the Null Hypothesis.” Crime and Justice 30: 143-195.

Durlauf, Steven N., and Nagin, Daniel S. 2010. "The deterrent effect of imprisonment." In Controlling Crime: Strategies and Tradeoffs, NBER Chapters. National Bureau of Economic Research, Inc. 
Ehrlich, Isaac. 1975. “The Deterrent Effect of Capital Punishment: A Question of Life and Death." American Economic Review 65(3): 397-417.

Ehrlich, Isaac. 1977. “Capital Punishment and Deterrence: Some Further Thoughts and Additional Evidence.” Journal of Political Economy 85(4): 741-88

Elo, Irma T, Rosalind Berkowitz King, and Frank F. Furstenberg. 1999. "Adolescent Females: Their Sexual Partners and the Fathers of their Children." Journal of Marriage and the Family 61(1): 74-84.

Eterno, John A., and Eli B. Silverman. 2012. The Crime Numbers Game: Management by Manipulation (Advances in Police Theory and Practice). CRC Press; 1st edition.

Frakes, Michael. 2013. The Impact of Medical Liability Standards on Regional Variations in Physician Behavior: Evidence from the Adoption of National-Standard Rules, 103 American Economic Review 1: 257-76.

Frakes, Michael, and Matthew Harding. 2009. "The Deterrent Effect of Death Penalty Eligibility: Evidence from the Adoption of Child Murder Eligibility Factors." American Law and Economics Review 11(2): 451-497.

Government Accountability Office (GAO). 1994. “AFDC Women Who Gave Birth as Teenagers." GAO/HHS94-115.

Gross, Tal and Matthew Notowodigdo. 2011. "Health Insurance and the Consumer Bankruptcy Decision: Evidence from Medicaid.” Journal of Public Economics 95 (7-8). Gruber, Jonathan. 1994. "The Incidence of Mandated Maternity Benefits," American Economic Review 84: 622-41. 
Gruber, Jonathan, and Kosali Simon. 2008. “Crowd-out 10 years later: Have recent public insurance expansions crowded out private health insurance?" Journal of Health Economics 27: 201-217.

Gruber, Jonathan, and Aaron Yelowtiz. 1999. "Public Health Insurance and Private Savings.” Journal of Political Economy 107(6): 1249=74.

Gruber, Jonathan, and Daniel M. Hungerman. 2008. "Church versus the Mall: What Happens When Religion Faces Increased Secular Competition.” Quarterly Journal of Economics, 123(2): 831-62.

Helland, Eric, and Alexander Tabarrok. 2007. "Does Three Strikes Deter?: A Nonparametric Estimation." Journal of Human Resources 42(2): 309-330

Henry, Matthew, and Scott Cunningham. 2010. "Do Statutory Rape Laws Work?" http://papers.ssrn.com/sol3/papers.cfm?abstract_id=1443273.

Jepsen, Christopher, and Lisa Kay Jepsen. 2006. "The Effects of Statutory Rape Laws on Nonmarital Teenage Childbearing." Contemporary Economic Policy 24(1): 35-51.

Kahneman, Daniel. 2012. Thinking Fast and Slow. Farrar, Straus and Giroux, New York. Kahneman, Daniel, and Amos Tversky. 1979. "Prospect Theory: An Analysis of Decision under Risk.” Econometrica 47(2): pp. 263-292.

Kaiser Family Foundation. 2003. "Teens and TANF: How Adolescents Fare Under the Nation's Welfare Program.” Issue Brief: An Update on Women's Health Policy.

Kearney, Melissa S., and Phillip B. Levine. 2012. "Why Is the Teen Birth Rate in the United States So High and Why Does It Matter?" Journal of Economic Perspectives, 26(2): 141-63. 
Lawlor, Debbie, and Mary Shaw. 2002. "Too much too young: Teenage pregnancy is not a public health problem." International Journal of Epidemiology 31: 552-3.

Lee, David S., and Justin McCrary. 2009. “The Deterrence Effect of Prison: Dynamic Theory and Evidence." CEPS Working Paper No. 189.

Levitt, Steven D. 1996. “The Effect of Prison Population Size on Crime Rates: Evidence from Prison Overcrowding Litigation." Quarterly Journal of Economics 111(2): 31951.

Levitt, Steven D. 1997. "Using Electoral Cycles in Police Hiring to Estimate the Effect of Police on Crime," American Economic Review 87(3): 270-90.

Levitt, Steven D. 1998. “Juvenile Crime and Punishment.” Journal of Political Economy 106(6): 1156-1185.

Levitt, Steven D. 1998. "Why Do Increased Arrest Rates Appear to Reduce Crime: Deterrence, Incapacitation, or Measurement Error?" Economic Inquiry 36(3): 353-72.

Lovenheim, Michael F., and Daniel P. Steefel. 2011. "Do blue laws save lives? The effect of Sunday alcohol sales bans on fatal vehicle accidents." Journal of Policy Analysis and Management 30(4): 798-820.

McCrary, Justin. 2002. "Using Electoral Cycles in Police Hiring to Estimate the Effect of Police on Crime: Comment." American Economic Review 92(4).

Nagin, Daniel. 1998. "Criminal Deterrence Research at the Outset of the Twenty-First Century." In Crime and Justice: A Review of Research, vol. 23. Michael Tonry, ed. Chicago: University of Chicago Press. 
Osgood, D. Wayne. 2000. "Poisson-Based Regression Analysis of Aggregate Crime Rates." Journal of Quantitative Criminology 16(1): 21-43.

Prescott, J.J., and Jonah E. Rockoff. 2011. “Do Sex Offender Registration and Notification Laws Affect Criminal Behavior?" Journal of Law and Economics 54(1): 161-206.

Rupp, Thomas. 2008. "Meta analysis of crime and deterrence : a comprehensive review of the literature." Dissertation. Publications of Darmstadt Technical University, Institute of Economics (VWL) 30959, Darmstadt Technical University, Department of Business Administration, Economics and Law, Institute of Economics (VWL).

Scally, Gabriel. 2002. "Too much too young? Teenage Pregnancy is a public health problem, not a clinical option." International Journal of Epidemiology 31: 554-5.

Sutherland, Kate. 2003. "From Jailbird to Jailbait: Age of Consent Laws and the Construction of Teenage Sexualities." William \& Mary Journal of Women and the Law 9: 313-49. 
Appendix

\section{Evolution of State Statutory Rape Laws: Background}

Over the course of the sample period, nearly every state modified some aspect of its statutory rape laws, often increasing the punishment associated with at least one degree of statutory rape. The full extent of these variations are available upon request. For the sake of brevity, we do not set forth all such details in this Appendix. Nonetheless, to illuminate the primary results from Table 2 in the text, we summarize in Table A1 those variations in state statutory rape laws along the initial-criminalization margin, focusing only on expansions in the law (i.e., those laws underlying Panel A of Table 2). As discussed later, our primary approach views this initial criminalization threshold as being crossed once an activity triggers a felony statute, thus effectively disregarding (for now) misdemeanors.

\section{Non-parametric Treatment of Felony Incidence Variable}

The felony incidence variable is treated linearly within our primary specifications. In Table A2, we present results from a more non-parametric approach, where we divide the felony incidence variable into four quartiles and estimate the association between live birth rates and the incidence of moving into a higher felony incidence quartile (where a higher quartile represents an increase in the degree to which the laws of the relevant state-yearage criminalize sexual encounters among that age group).

The results presented in Table A2 suggest a possible non-linear impact of expanding the degree to which sexual activity is initially criminalized among a particular age group, with 
the bulk of the impact felt when moving into the higher ranges of the felony-incidence distribution.

\section{Further Punishment Severity Specifications}

In Table A4, we expand upon Table 3 from the text and estimate specifications that include more than just two punishment severity bins. We actually begin this extension by considering a less severe category. That is, in Columns 1 and 2 of Table A4, we modify the specifications estimated in Table 3 to add measures capturing the simulated percentage of sexual encounters triggering only a misdemeanor statute in the relevant state-year-age cell-that is, a statute in which the maximum imprisonment associated with the relevant infraction is less than 1 year (generally around six months). The estimated coefficients of the basic-felony incidence variable and the heightened-felony incidence variable are nearly identical to that estimated in Table 3. The estimated coefficients of the simulated misdemeanor incidence variables are negative in sign; though the estimates are noisy and fail to establish convincing evidence of a deterrent impact from moving into misdemeanor status.

The noise associated with the misdemeanor coefficients is perhaps not surprising. When states expand their laws to criminalize a broader range of sexual activity, they almost predominantly do so by making the newly covered behavior a felony. There are only very rare instances over the sample period when states expand their statutory rape laws to criminalize new behavior in only a misdemeanor context, leaving little information by which to estimate this separate margin. Moreover, even in such instances, one may be 
concerned that misdemeanor violations are heavily unenforced relative to felony statutes, attenuating the results. Note that when we estimate specifications that simulate the percentage of sexual encounters that trigger any crime-felony or misdemeanor-we estimate virtually identical results to those presented in Table $2^{33}$

Columns 3 and 4 of Table A4 add one additional punishment severity bin covering punishments of the highest degree-generally, those carrying a minimum incarceration range of 20-plus years. The estimated coefficient of the simulated incidence of these extraheightened felonies is noisy and statistically indistinguishable from zero. However, the point estimates suggest a negative relationship consistent with the initial-felony findings, though of a more modest magnitude (a roughly 7-8 percent reduction in live birth rates). As such, adding this final category does not substantially change the conclusion that the reduction in teenage sexual behavior associated with statutory rape laws appears to arise mostly from the fundamental criminalization of certain activities itself.

\section{Count Specifications}

As indicated in the text, the Ordinary Least Squares (OLS) approach taken is perhaps appropriate considering an average of roughly 890 live births within each state-year-age cell, along with an average denominator for the live birth rate-that is, the female population—of roughly 37,000. With cell sizes this large, the estimated birth rates are not necessarily so discrete in nature as to warrant a count model. This is arguably the case

\footnotetext{
${ }^{33}$ For instance, the estimated coefficient of the simulated any-crime-incidence variable in the full triple-differences specification (analogous to Column 3 of Table 2) is roughly -10 (likewise significant at 1\%), suggesting only a small amount of attenuation as a result of including the misdemeanor-only adoptions. The full set of results from this alternative specification is available upon request.
} 
even with respect to the younger ages, where live birth counts per cell are smaller but where female population counts are nonetheless sufficiently large to generate continuity in the calculated birthrates. Moreover, there are only 23 instances of zero-valued cells out of nearly 7000 state-year-age cells, in which event there is little concern in log transforming the birthrate dependent variable in order to better achieve normality. For these reasons, we estimate OLS specifications in our primary approach.

Nonetheless, as a robustness exercise, in Table A5, we estimate Poisson regression specifications. We have likewise estimated Negative Binomial specifications, though we omit the results (available upon request) as they are nearly identical to the Poisson results (tests reject the presence of over-dispersion). The results from Poisson regressions are generally consistent with those from the primary OLS specifications. In Column 1, estimating a basic difference-in-difference specification with only state, age and year fixed effects, we find an incidence-rate ratio for the simulated felony incidence variable coefficient of $93 \%$ suggesting a $7 \%$ reduction in the rate of live births following a move from 0 to 100 percent felonization of sexual activity among the given age group.

This estimate is robust to the inclusion of state-year covariates (Column 2), state-year fixed effects (Column 3), and state-age-specific linear time trends (Column 4). As such, the Poisson results appear robust to the possibility of unobservable state-specific initiatives adopted over the sample period that likewise bear on teenage pregnancies. Unlike the OLS specifications, however, the estimated felony incidence coefficient falls by half and loses statistical significance with the addition of the state-age fixed effects (357 fixed effects) 
and age-year fixed effects (161 fixed effects) necessary to implement the full tripledifferences specification.

\section{$\underline{\text { Randomization Inference }}$}

Standard errors may be inaccurately estimated in difference-in-difference or tripledifferences specifications when there are a limited number of overall analytical or treatment groups (Bertrand et al. 2004, Conley and Taber 2005). While the above specifications draw on a large number of treatment and control states, we perform hypothesis tests on the estimated felony-incidence coefficient from the main tripledifferences specification using a randomization inference approach (Duflo et al. 2007) that allows for an estimation of the distribution of the treatment effect that is valid under any number of groups. Using only the set of states that did not expand their statutory rape laws over the sample period to newly felonize a range of a sexual activity, we randomly generate 1,000 sets of placebo laws and estimate the primary triple-differences specification on each of these simulated sets. We simulate the placebos so that the expected distribution of stateyear-age-specific placebo law changes over time matches the distribution of actual law changes (Gruber and Hungerman 2008; Frakes 2013) and matches the expansion magnitudes (in terms of percentage of sexual activity felonized) actually observed. We find that the estimated coefficient of the simulated felony incidence variable (using the actual variation in the laws) falls in the $0.4^{\text {th }}$ percentile of the empirical distribution of the 1000 estimated coefficients from the simulations, consistent with a p-value of $<0.1$. We limit the simulation number to 1,000 due to the substantial required computational time. 


\section{Falsification Exercise: Nearby Adult Live Birth Rates}

Expansions in statutory rape laws should only be expected to reduce live births in the targeted population. This expectation forms the basis of the above triple differences analysis, in which we use non-reformed age groups as within-state control groups. One would also not expect expansions in statutory rape laws within a state to be associated with a corresponding reduction in the live birth rates of the nearby adult population, as that population was likewise not the target of the associated reforms. If anything, to the extent that the deterred sexual encounters with minors induces some offenders to seek matches with partners closer to their own age, such expansions might be associated with a slight increase in pregnancy rates of this older population. In Table A6, we perform this hypothesis test in a simple difference-in-difference framework and estimate the association between the percentage of sexual activity among 12-17 year olds that triggers a felony within the operable state-year cell (i.e., our codification of the scope of the prevailing statutory rape regime) and the live birth rates of 18 year-olds (Column 1), 19 year-olds (Column 2) and 20 year-olds (Column 3), in each case where the live birth rates are formed based on estimated ages and years at the time of conception (as above). As expected, in each case, we estimate a positive statistically-insignificant coefficient of the simulated statutory rape variable.

\section{Heterogeneity in Treatment Effects across Races}

As suggested in the text, true violations of statutory rape laws appear to be heavily underenforced, with much discretion left in play on the part of the police and prosecutors (and 
on the part of parents engaging such parties) to decide on which instances to pursue. Discretionary situations of this nature lead to concerns of selective enforcement. Evidence to date suggests that this selection has tended heavily to target black and Hispanic males as offenders of statutory rape violations. According to incarceration data from Georgia, those in jail for offenses against children generally are more likely to be white males (e.g., $67 \%$ white in the case of child-molestation offenses); however, in the context of statutory rape, those incarcerated for this offense are actually more likely to be black males (i.e., $55 \%$ black).

According to Richard Delgado (1996):

Unable to prosecute the whole country, law enforcement officials apply the law principally against two groups: men, frequently older, who have sex with girls from "good homes;" and minority men, who are punished if they commit the crime of having sex with white women or impregnate a woman of color under circumstances that add to the welfare rolls.

Sutherland (2003) adds to Delgado's claim:

The California Alliance for Statutory Rape Enforcement's mostwanted list provides some evidence to back up Delgado's claim about the likelihood of minority men being targeted for prosecution. Of the thirty-five people featured on the list in March 2003, thirty-two were men. All thirty-two of these men were identified as Hispanic or black. 
If minority males are more likely to be the targets of statutory rape enforcement, one might predict that the impact of statutory rape law expansions would be more impactful in regions with higher rates of black residents. For a simple test of this claim, we modify the triple-differences specification to include an interaction between the felony-incidence variable and the percentage of the state-year-age population that is black. We find a large negative estimate of the interaction term (-22.2) consistent with these expectations; though this estimate is rather noisy and not distinguishable from zero (full results available upon request).

While minority men may be more likely targets of statutory rape violations, that does not immediately entail that sexual encounters involving black females are more likely to be those garnering attention from the authorities. After all, heightened enforcement may be targeted at black males having intercourse with white females (Delgado 1996). However, much of statutory rape enforcement is also targeted against black males who have had intercourse with black females leading to pregnancies, where the parties generally bringing these legal violations to the attention of criminal justice system are those working at welfare offices (Sutherland 2003). As such, it is perhaps reasonable to believe that expansions in the scope of statutory rape laws will have a larger impact on the live birth rates of black females relative to white females. To test this hypothesis, we simply estimate separate specifications where the dependent variable is the live birth rate specific to white, black and other-race females, respectively. As demonstrated by Table A7, the strongest findings are indeed in the context of black and other-race females relative to white females.

\section{Abortion-Rate Specifications}


The primary analysis focuses on live birth rates for several reasons. Largely, we are able to collect comprehensive live birth rates for each state for as far back in time as were able to track the evolution of state statutory rape laws. Such rates provide us with a general proxy for the targeted sexual activity of statutory rape laws, facilitating a general deterrence analysis. At the same time, of course, this specific relationship between live birth rates and statutory rape laws has been of substantial interest to policymakers themselves.

Of course, other proxies for sexual activity are potentially available, including abortion rates. Pregnancies, after all, can end in one of miscarriage, abortion, still birth or live birth. In Table A8, we estimate the relationship between state-year-age-specific abortion rates (logged) and the percentage of sexual activity among the state-year-age cell that triggers a felony. Abortion data, however, are only available for 46 states between 1991 and 2004 and were obtained from the Centers for Disease Control (CDC). Moreover, given the structure of the CDC data, the 13 and 14 year-old groups are consolidated together. The difference-in-difference specifications suggest a marginally significant reduction of nearly 14 percent in the relevant abortion rate upon an increase from 0 to 100 percent in the felonization of sexual activity among the relevant age group (Column 1). This finding remains nearly unchanged with the inclusion of the state-year covariates considered in Table 2 (Column 2), along with the inclusion of state-year fixed effects (Column 3). We note, however, that we have not codified and controlled for all other state-based policies bearing on the ease by which minors may obtain abortions. Future work would benefit from the inclusion of such controls. Nonetheless, to the extent that such additional policies 
are not targeted at specific ages, many of them may be subsumed by the state-year fixed effects.

As such, these specifications provide some support for an interpretation of the live-birthrate findings as emanating from a deterrence of underlying sexual behavior, as opposed to arising from an increase in abortions in order to avoid detection of a statutory rape violation. ${ }^{34}$ However, upon the addition of the state-age and age-year fixed effects (i.e., the full triple-differences specification), the coefficient of the simulated felony incidence variable changes sign (Column 4). Even in those cases, however, the estimates are statistically indistinguishable from zero.

\footnotetext{
34 As indicated in the text, the fact of a statutory-rape-law violation may be more likely to come to light in the event of a pregnancy. As such, with the expansion of a statutory rape law, potential offenders seeking to avoid the associated penalties may either reduce the sexual activity truly targeted by the law or they may continue to engage in the activity but attempt to circumvent detection-e.g., by using contraception at higher frequencies or by encouraging abortions by their partners. These latter attempts, however, may be of limited effect to the extent that abortion procedures likewise trigger some possibility of detection of statutory rape violations. Some jurisdictions have passed laws requiring certain health care providers to notify the police and related offices of knowledge of statutory rape violations. In future work, we hope to codify such expansions in the law (a challenging exercise given the pre-existence of general child-abuse notification statutes that may or may not have encapsulated statutory rape violations).
} 
Table 1

Summary Statistics

\begin{tabular}{|c|c|c|c|c|c|c|c|}
\hline & $\begin{array}{l}\text { OVER- } \\
\text { ALL } \\
\end{array}$ & $\begin{array}{l}12 \text { YEAR } \\
\text { OLDS }\end{array}$ & $\begin{array}{l}13 \text { YEAR } \\
\text { OLDS } \\
\end{array}$ & $\begin{array}{c}14 \text { YEAR } \\
\text { OLDS }\end{array}$ & $\begin{array}{l}15 \text { YEAR } \\
\text { OLDS }\end{array}$ & $\begin{array}{c}16 \text { YEAR } \\
\text { OLDS }\end{array}$ & $\begin{array}{c}17 \text { YEAR } \\
\text { OLDS } \\
\end{array}$ \\
\hline \multicolumn{8}{|c|}{ Panel A: State-Year-Age Variables } \\
\hline Statutory Rape Law Varial & & & & & & & \\
\hline $\begin{array}{l}\text { Simulated Incidence of Any } \\
\text { Felony }\end{array}$ & $\begin{array}{c}0.47 \\
(0.42)\end{array}$ & $\begin{array}{c}0.82 \\
(0.29)\end{array}$ & $\begin{array}{c}0.70 \\
(0.31)\end{array}$ & $\begin{array}{c}0.54 \\
(0.36)\end{array}$ & $\begin{array}{c}0.45 \\
(0.38)\end{array}$ & $\begin{array}{c}0.18 \\
(0.32)\end{array}$ & $\begin{array}{c}0.12 \\
(0.31)\end{array}$ \\
\hline $\begin{array}{l}\text { Simulated Basic Felony } \\
\text { Incidence (1-10 years } \\
\text { minimum) }\end{array}$ & $\begin{array}{c}0.44 \\
(0.41)\end{array}$ & $\begin{array}{c}0.70 \\
(0.38)\end{array}$ & $\begin{array}{c}0.66 \\
(0.33)\end{array}$ & $\begin{array}{c}(0.52) \\
0.36\end{array}$ & $\begin{array}{c}0.45 \\
(0.38)\end{array}$ & $\begin{array}{c}0.18 \\
(0.32)\end{array}$ & $\begin{array}{c}0.12 \\
(0.31)\end{array}$ \\
\hline $\begin{array}{l}\text { Simulated Any Heightened } \\
\text { Felony Incidence }(10+ \\
\text { years minimum) }\end{array}$ & $\begin{array}{c}0.03 \\
(0.16)\end{array}$ & $\begin{array}{c}0.12 \\
(0.29)\end{array}$ & $\begin{array}{c}0.04 \\
(0.18)\end{array}$ & $\begin{array}{c}0.02 \\
(0.13)\end{array}$ & $\begin{array}{c}0.00 \\
(0.03)\end{array}$ & $\begin{array}{c}0.00 \\
(0.00)\end{array}$ & $\begin{array}{c}0.00 \\
(0.00)\end{array}$ \\
\hline $\begin{array}{l}\text { Simulated Expected } \\
\text { Minimum Incarceration } \\
\text { Level (years) }\end{array}$ & $\begin{array}{l}1.30 \\
(2.94)\end{array}$ & $\begin{array}{c}3.72 \\
(5.49)\end{array}$ & $\begin{array}{c}2.00 \\
(2.75)\end{array}$ & $\begin{array}{c}1.04 \\
(1.88)\end{array}$ & $\begin{array}{c}0.69 \\
(0.75)\end{array}$ & $\begin{array}{c}0.23 \\
(0.35)\end{array}$ & $\begin{array}{c}0.13 \\
(0.32)\end{array}$ \\
\hline $\begin{array}{l}\text { Simulated Expected Mean } \\
\text { Incarceration Level } \\
\text { (years) }\end{array}$ & $\begin{array}{c}5.66 \\
(8.31)\end{array}$ & $\begin{array}{c}13.54 \\
(10.08)\end{array}$ & $\begin{array}{c}8.95 \\
(9.37)\end{array}$ & $\begin{array}{c}4.97 \\
(6.67)\end{array}$ & $\begin{array}{c}4.02 \\
(5.79)\end{array}$ & $\begin{array}{c}1.37 \\
(3.77)\end{array}$ & $\begin{array}{c}0.95 \\
(3.72)\end{array}$ \\
\hline \multicolumn{8}{|l|}{ Other Variables } \\
\hline $\begin{array}{l}\text { Live Birth Rate (Per 1,000 } \\
\text { females) }\end{array}$ & $\begin{array}{c}24.84 \\
(25.91)\end{array}$ & $\begin{array}{c}0.69 \\
(0.46)\end{array}$ & $\begin{array}{c}3.48 \\
(1.82)\end{array}$ & $\begin{array}{l}11.21 \\
(5.02)\end{array}$ & $\begin{array}{c}25.13 \\
(10.03)\end{array}$ & $\begin{array}{c}44.09 \\
(15.87)\end{array}$ & $\begin{array}{l}64.88 \\
(20.81)\end{array}$ \\
\hline $\begin{array}{l}\text { Live Birth Counts } \\
\quad \text { (unweighted) }\end{array}$ & $\begin{array}{c}840.28 \\
(1573.13)\end{array}$ & $\begin{array}{c}23.59 \\
(30.76)\end{array}$ & $\begin{array}{c}119.05 \\
(151.44)\end{array}$ & $\begin{array}{c}380.36 \\
(485.07)\end{array}$ & $\begin{array}{c}852.65 \\
(1062.12)\end{array}$ & $\begin{array}{c}1463.85 \\
(1784.05)\end{array}$ & $\begin{array}{c}2182.06 \\
(2566.68)\end{array}$ \\
\hline
\end{tabular}

\section{Panel B: State-Year Variables}

$\begin{array}{lc}\text { Arrests for Non-Forcible } & \\ \text { Rape Sex Offenses Per } & 1.6 \\ \text { 1,000 Population (18-30 } & (0.86) \\ \text { year-old males) } & \\ \text { Arrests for Forcible Rape } & \\ \quad \text { Sex Offenses Per 1,000 } & 0.74 \\ \quad \text { Population (18-30 year- } & (0.36)\end{array}$

old males)

Notes: data in Panel A are from a sample of 6,758 state-year-age cells. Live birth rates are from the Natality Detail Files of the National Vital Statistics Data. State-year-age population data (with percentage black) are from the U.S. Census Bureau and were collected from the National Cancer Institute, a division of the United States National Institutes of Health. The underlying data applied to the statutory rape laws of each state-year-age cell used to form the simulated statutory rape law variables are from the 1996 and 2002 arms of the National Survey of Family Growth. All measures (except for the female population total and the unweighted live birth count) are weighted by the associated female population of the state-year-age cell. Data in Panel B are from the FBI's Uniform Crime Reports. 
Table 2

Relationship between Live Birth Rates (Logged) and Simulated Percentage of Sexual Activity

that Triggers a Felony

\begin{tabular}{|c|c|c|c|c|c|c|c|c|}
\hline & $(1)$ & $(2)$ & $(3)$ & (4) & $(5)$ & $(6)$ & (7) & $(8)$ \\
\hline \multicolumn{9}{|c|}{ Panel A. Primary Specifications: Expansion-only Variations in Statutory Rape Laws } \\
\hline $\begin{array}{l}\text { Simulated Felony } \\
\text { Percentage: } \\
\text { 4-Year Lead }\end{array}$ & - & - & - & - & - & - & $\begin{array}{c}0.1 \\
(5.4)\end{array}$ & $\begin{array}{l}1.54 \\
(5.5)\end{array}$ \\
\hline $\begin{array}{l}\text { Simulated Felony } \\
\text { Percentage: } \\
\text { 2-Year Lead }\end{array}$ & - & - & - & - & - & - & $\begin{array}{c}0.9 \\
(4.6)\end{array}$ & $\begin{array}{l}-0.3 \\
(5.2)\end{array}$ \\
\hline $\begin{array}{l}\text { Simulated Felony } \\
\text { Percentage }\end{array}$ & $\begin{array}{c}-11.5^{*} \\
(5.5)\end{array}$ & $\begin{array}{c}-10.7 * \\
(5.3)\end{array}$ & $\begin{array}{c}-12.5^{+} \\
(6.7)\end{array}$ & $\begin{array}{r}-13.0^{*} \\
(5.9)\end{array}$ & $\begin{array}{c}-12.7^{*} \\
(5.8)\end{array}$ & $\begin{array}{c}-19.1 * * \\
(5.7)\end{array}$ & $\begin{array}{c}-13.8^{*} \\
(6.4)\end{array}$ & $\begin{array}{c}-24.1^{*} \\
(9.3)\end{array}$ \\
\hline $\begin{array}{l}\text { Simulated Felony } \\
\text { Percentage: } \\
\text { 2-Year Lag }\end{array}$ & - & - & - & - & - & - & - & $\begin{array}{c}2.6 \\
(9.0)\end{array}$ \\
\hline $\begin{array}{l}\text { Simulated Felony } \\
\text { Percentage: } \\
\text { 4-Year Lag }\end{array}$ & - & - & - & - & - & - & - & $\begin{array}{c}8.5 \\
(1.5)\end{array}$ \\
\hline Percentage Black & - & - & - & - & $\begin{array}{l}238.6^{*} \\
(95.7)\end{array}$ & - & - & - \\
\hline $\mathrm{N}$ & 6525 & 6437 & 6525 & 6525 & 6437 & 6525 & 6525 & 5402 \\
\hline \multicolumn{9}{|c|}{ Panel B. Alternative Specifications: Expansions and Contractions in Statutory Rape Laws } \\
\hline $\begin{array}{l}\text { Simulated Felony } \\
\text { Percentage: } \\
\text { 4-Year Lead }\end{array}$ & - & - & - & - & - & - & $\begin{array}{c}0.8 \\
(5.1)\end{array}$ & $\begin{array}{c}2.2 \\
(5.2)\end{array}$ \\
\hline $\begin{array}{l}\text { Simulated Felony } \\
\text { Percentage: } \\
\text { 2-Year Lead }\end{array}$ & - & - & - & - & - & - & $\begin{array}{c}2.9 \\
(5.1)\end{array}$ & $\begin{array}{c}2.0 \\
(5.8)\end{array}$ \\
\hline $\begin{array}{l}\text { Simulated Felony } \\
\text { Percentage }\end{array}$ & $\begin{array}{l}-4.7 \\
(5.4)\end{array}$ & $\begin{array}{l}-4.7 \\
(5.0)\end{array}$ & $\begin{array}{l}-10.7 \\
(6.5)\end{array}$ & $\begin{array}{c}-10.6^{*} \\
(4.5)\end{array}$ & $\begin{array}{l}-9.0 * \\
(4.1)\end{array}$ & $\begin{array}{l}-5.9 \\
(5.1)\end{array}$ & $\begin{array}{c}-13.5^{* * *} \\
(4.2)\end{array}$ & $\begin{array}{c}-14.1^{+} \\
(8.3)\end{array}$ \\
\hline $\begin{array}{l}\text { Simulated Felony } \\
\text { Percentage: } \\
\text { 2-Year Lag }\end{array}$ & - & - & - & - & - & - & - & $\begin{array}{c}0.1 \\
(6.9)\end{array}$ \\
\hline $\begin{array}{l}\text { Simulated Felony } \\
\text { Percentage: } \\
\text { 4-Year Lag }\end{array}$ & - & - & - & - & - & - & - & $\begin{array}{c}0.5 \\
(4.1)\end{array}$ \\
\hline Percentage Black & - & - & - & - & $\begin{array}{l}238.0 * \\
(91.4)\end{array}$ & - & - & - \\
\hline $\mathrm{N}$ & 6759 & 6668 & 6759 & 6759 & 6668 & 6759 & 6759 & 5601 \\
\hline $\begin{array}{l}\text { State-Year } \\
\quad \text { Covariates }\end{array}$ & NO & YES & NO & NO & NO & NO & NO & NO \\
\hline $\begin{array}{l}\text { State-Year Fixed } \\
\text { Effects? }\end{array}$ & NO & NO & YES & YES & YES & YES & YES & YES \\
\hline Age-Year Effects? & NO & NO & NO & YES & YES & YES & YES & YES \\
\hline State-Age Effects? & $\mathrm{NO}$ & $\mathrm{NO}$ & NO & YES & YES & YES & YES & YES \\
\hline $\begin{array}{c}\text { State-Age-Specific } \\
\text { Linear Trends }\end{array}$ & NO & NO & NO & NO & NO & YES & NO & NO \\
\hline
\end{tabular}

Notes: robust standard errors corrected for within-state correlation in the error term are reported in parentheses. Estimated statistics are multiplied by 100. All regressions include state, age and year fixed effects and are weighted by the female population of the associated state-year-age cell. Live birth rate data are from the Natality Detail Files.

** Significant at the 1 percent level.

* Significant at the 5 percent level.

+ Significant at the 10 percent level. 
Table 3

Relationship between Live Birth Rates (Logged) and Simulated Percentage of Sexual Activity that Triggers a Crime Within Two Felony Punishment Tiers

$(1)+(3) \quad(4)-(5)$

(7)

$\underline{\text { Simulated Basic }}$

Felony Incidence

4-Year Lead

2-Year Lead

Contemporaneous

$-11.7^{+}$

$-10.9^{+}$

(3)

(4)

(5)

2-Year Lag

(5.7)

$-12.4^{+}$

$-15.2 * *$

(7.1)

(5.5)

$-14.8 * *$

(5.5)

19.9 **

(5.6)

0.4

4-Year Lag

Simulated Heightened

Felony Incidence

4-Year Lead

2-Year Lead

Contemporaneous

2-Year Lag

- -
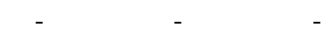

(5.0)

4-Year Lag

Percentage Black

$\mathrm{N}$

State-Year Covariates

State-Year Fixed Effects?

Age-Year Effects?

State-Age Effects?

State-Age-Specific Linear Time Trends

Notes: robust standard errors corrected for within-state correlation in the error term are reported in parentheses. Estimated coefficients and standard errors are multiplied by 100. All regressions include state, age and year fixed effects and are weighted by the female population of the associated state-year-age cell. Live birth rate data are from the Natality Detail Files.

** Significant at the 1 percent level.

* Significant at the 5 percent level.

+ Significant at the 10 percent level. 
Table 4

Relationship between Live Birth Rates (Logged) and Simulated Expected Minimum and Mean Incarceration Rates Associated With Sexual Activity among Relevant Ages

\begin{tabular}{|c|c|c|c|c|c|c|}
\hline & $(1)$ & $(2)$ & (3) & $(4)$ & $(5)$ & $(6)$ \\
\hline \multicolumn{7}{|l|}{ Felony Incidence } \\
\hline $\begin{array}{l}\text { Simulated Percentage: 4- } \\
\text { Year Lead }\end{array}$ & - & - & $\begin{array}{c}0.9 \\
(5.9)\end{array}$ & - & - & $\begin{array}{l}2.0 \\
(6.9)\end{array}$ \\
\hline $\begin{array}{l}\text { Simulated Percentage: 2- } \\
\text { Year Lead }\end{array}$ & - & - & $\begin{array}{l}0.3 \\
(5.6)\end{array}$ & - & - & $\begin{array}{l}-2.0 \\
(5.8)\end{array}$ \\
\hline Simulated Percentage & - & $\begin{array}{l}-15.2 * \\
(5.8)\end{array}$ & $\begin{array}{l}-15.9^{*} \\
(6.0)\end{array}$ & - & $\begin{array}{r}-19.2^{* *} \\
(5.5)\end{array}$ & $\begin{array}{c}-18.8^{* *} \\
(5.7)\end{array}$ \\
\hline Expected Minimum & & & & & & \\
\hline \multicolumn{7}{|l|}{ Length (Years) } \\
\hline $\begin{array}{l}\text { Simulated Expected Minimum: 4- } \\
\text { Year Lead }\end{array}$ & - & - & $\begin{array}{l}-0.18 \\
(0.38)\end{array}$ & - & - & - \\
\hline $\begin{array}{l}\text { Simulated Expected Minimum: 2- } \\
\quad \text { Year Lead }\end{array}$ & - & - & $\begin{array}{c}0.20 \\
(0.77)\end{array}$ & - & - & - \\
\hline Simulated Expected Minimum & $\begin{array}{c}0.1 \\
(0.2)\end{array}$ & $\begin{array}{c}0.3 \\
(0.3)\end{array}$ & $\begin{array}{c}0.26 \\
(0.63)\end{array}$ & - & - & - \\
\hline \multicolumn{7}{|l|}{$\frac{\text { Expected Mean Incarceration Length }}{\text { (Years) }}$} \\
\hline $\begin{array}{l}\text { Simulated Expected Mean: 4- } \\
\text { Year Lead }\end{array}$ & - & - & - & - & - & $\begin{array}{l}-0.2 \\
(0.3)\end{array}$ \\
\hline $\begin{array}{l}\text { Simulated Expected Mean: 2- } \\
\text { Year Lead }\end{array}$ & - & - & - & - & - & $\begin{array}{c}0.3 \\
(0.4)\end{array}$ \\
\hline Simulated Expected Mean & - & - & - & $\begin{array}{c}0.0 \\
(0.2)\end{array}$ & $\begin{array}{l}0.3 \\
(0.2)\end{array}$ & $\begin{array}{c}0.2 \\
(0.4)\end{array}$ \\
\hline $\mathrm{N}$ & 6543 & 6519 & 6519 & 6543 & 6519 & 6519 \\
\hline
\end{tabular}

Notes: robust standard errors corrected for within-state correlation in the error term are reported in parentheses. Estimated coefficients and standard errors are multiplied by 100. All regressions include state, age and year fixed effects, along with state-year effects, age-year effects and state-age effects. Regressions are weighted by the female population of the associated state-year-age cell. Live birth rate data are from the Natality Detail Files. .

** Significant at the 1 percent level.

* Significant at the 5 percent level.

+ Significant at the 10 percent level. 
Table 5

Relationship between Live Birth Rates (Logged) and State-Year Sex-Offense Arrest Rates

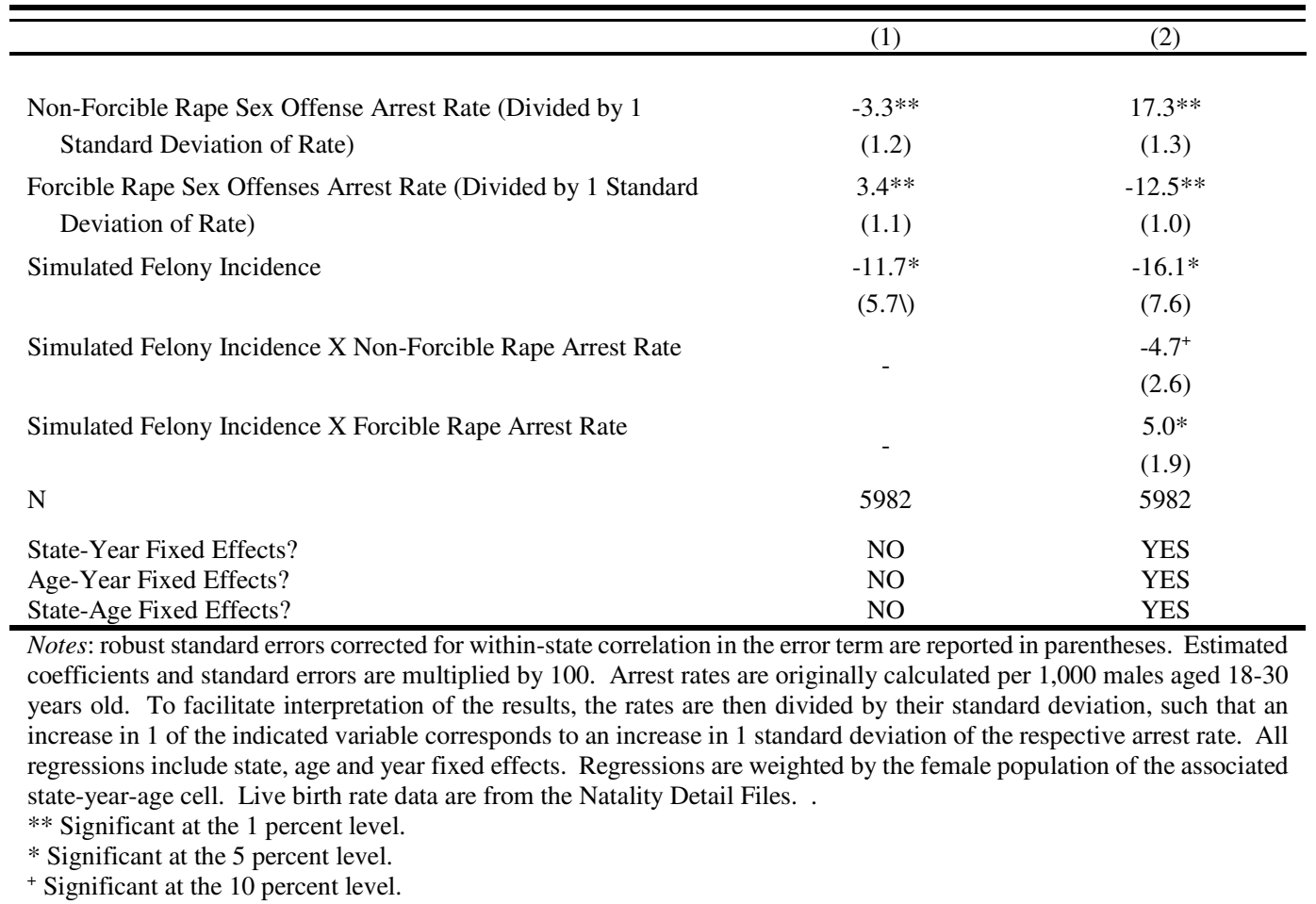


Table 6

Heterogeneity in Treatment Effects by Age

(1)

(Omitted category: 17 Year Olds)

Simulated Felony Incidence

Simulated Felony Incidence X 12-Year Old Dummy

$-72.6^{* * *}$

(21.4)

Simulated Felony Incidence X 13-Year Old Dummy

$-65.0^{* * *}$

(23.0)

Simulated Felony Incidence X 14-Year Old Dummy

$-60.1 * *$

Simulated Felony Incidence X 15-Year Old Dummy

Simulated Felony Incidence X 16-Year Old Dummy

Notes: robust standard errors corrected for within-state correlation in the error term are reported in parentheses. Estimated coefficients and standard errors are multiplied by 100. All regressions include state, age and year fixed effects, along with state-year effects, age-year effects and state-age effects. Regressions are weighted by the female population of the associated state-year-age cell. Live birth rate data are from the Natality Detail Files.

** Significant at the 1 percent level.

* Significant at the 5 percent level.

+ Significant at the 10 percent level. 
Table A1

Summary of Expansions in Statutory Rape Law Reforms along Initial-Criminalization Margin

\begin{tabular}{|c|c|c|c|}
\hline State & Year & Ages Affected & Nature of Expansion \\
\hline Arkansas & 1985 & $11,12,13$ & $\begin{array}{l}\text { Lifting of previous requirement that defendant } \\
\text { (D) be at least } 18 \text { years old }\end{array}$ \\
\hline \multirow[t]{3}{*}{ Connecticut } & 1985 & 15 & Age of consent increased from 15 to 16 \\
\hline & 1990 & $<=12,16$ & $\begin{array}{c}\text { Lifting of previous requirement that } \mathrm{D} \text { be at } \\
\text { least } 18 \text { years old }\end{array}$ \\
\hline & 1994 & $13,14,15$ & $\begin{array}{c}\text { Lifting of previous requirement that } D \text { be at } \\
\text { least } 18 \text { years old, but } 2 \text { year age-gap imposed } \\
\text { in its place }\end{array}$ \\
\hline Delaware & 1999 & 16,17 & $\begin{array}{l}\text { New degree added covering indicated ages } \\
\text { (previously uncovered), but only if D at least } \\
30 \text { years old }\end{array}$ \\
\hline Georgia & 1995 & 14,15 & Age of consent increased from 14 to 16 \\
\hline Hawaii & 2002 & 14,15 & $\begin{array}{c}\text { Age of consent increased from } 14 \text { to } 16 \text {, but } 5 \\
\text { year age-gap added for new group }\end{array}$ \\
\hline Louisiana & 2004 & 12 & $\begin{array}{c}\text { Lifting of previous requirement that } \mathrm{D} \text { be at } \\
\text { least } 18 \text { years old }\end{array}$ \\
\hline \multirow[t]{2}{*}{ Mississippi } & 1985 & 12,13 & $\begin{array}{c}\text { Age of consent increased from } 12 \text { to } 14 \text { years } \\
\text { old }\end{array}$ \\
\hline & 1998 & 14,15 & $\begin{array}{l}\text { Age of consent increased from } 14 \text { to } 16 \text { years } \\
\text { old (subject to } 3 \text { year age-gap for new group) }\end{array}$ \\
\hline North Carolina & 1996 & $13,14,15$ & $\begin{array}{c}\text { Age of consent increased from } 13 \text { to } 16 \text { years } \\
\text { old }\end{array}$ \\
\hline North Dakota & 2001 & $15,16,17$ & $\begin{array}{l}\text { Sex with } 15,16 \text { and } 17 \text { year olds now felony } \\
\text { (previously misdemeanor) if } \mathrm{D} \text { at least } 22 \\
\text { years old }\end{array}$ \\
\hline New Mexico & 1987 & $13,14,15$ & $\begin{array}{l}\text { Age of consent increased from } 13 \text { to } 17 \text { years } \\
\text { old (subject to } 4 \text { year age-gap for new group) }\end{array}$ \\
\hline Nevada & 1995 & 14,15 & $\begin{array}{c}\text { Age of consent increased from } 14 \text { to } 16 \text { years } \\
\text { old }\end{array}$ \\
\hline New York & 2001 & 14 & $\begin{array}{l}\text { Previously required } D \text { to be at least } 21 \text { years of } \\
\text { age, lowered to } 18 \text { years of age }\end{array}$ \\
\hline \multirow[t]{3}{*}{ Pennsylvania } & 1995 & 12 & $\begin{array}{l}\text { Lifted previous requirement that } \mathrm{D} \text { be at least } \\
\qquad 18 \text { years of age }\end{array}$ \\
\hline & 1995 & 13 & $\begin{array}{c}\text { Previously required } \mathrm{D} \text { to be at least } 18 \text { years of } \\
\text { age, amended to require age-gap of at least } 4 \\
\text { years }\end{array}$ \\
\hline & 1995 & 14,15 & Age of consent increased from 14 to $16 .^{*}$ \\
\hline Rhode Island & 1988 & 14 & $\begin{array}{l}\text { Lifted previous requirement that } \mathrm{D} \text { be at least } \\
\qquad 18 \text { years old }\end{array}$ \\
\hline South Carolina & 1984 & 12,13 & Lifting of prior 3-year age gap requirement \\
\hline South Dakota & 1985 & 15 & Age of consent raised from 15 to 16 years old \\
\hline \multirow[t]{2}{*}{ Washington } & 1988 & 12,13 & $\begin{array}{l}\text { Previous requirement that } \mathrm{D} \text { be greater than } 16 \\
\text { replaced with requirement that } \mathrm{D} \text { be at least } 3 \\
\text { years older, effectively criminalizing new } \\
\text { ranges of encounters (e.g., } 12 \text { year old victims } \\
\text { with } 15 \text { and } 16 \text { year old partners) }\end{array}$ \\
\hline & 1988 & 14 & $\begin{array}{l}\text { Previous requirement that } \mathrm{D} \text { be greater than } 18 \\
\text { replaced with requirement that } \mathrm{D} \text { be at least } 4 \\
\text { years older, effectively criminalizing new } \\
\text { ranges of encounters (e.g., } 14 \text { year old victims } \\
\text { with } 18 \text { year old partners) }\end{array}$ \\
\hline
\end{tabular}

* The documented variations concern Pennsylvania's relevant statutory rape statute. During the early 1970's, Pennsylvania's statutory rape statute covered this age group. However, Pennsylvania removed this age group from protection under the statute in 1976. It is possible that, during the interim 1976-1995 period, prosecutors could have pursued adults having intercourse with 14 and 15 year olds under an alternative sexual-deviance statute, given the technical language of such statute. However, it is unclear how often prosecutors 
pursued this alternative route. The question of whether it was even legally possible to take this alternative approach over this time period was also likely uncertain to the players at hand. Only one Pennsylvania appellate decision confronting this question could be found and it was resolved in the early 1990s, close to the point where the statute was modified anyway to allow statutory rape prosecutions based on this age group. In our primary approach, in light of the Commonwealth's explicit decision to remove this age group from their primary statutory rape provisions, we elect to treat this 1995 amendment as an expansion in the law to include this group. However, we note that in an alternative approach that registers no such expansion in the law for 14 and 15 year olds, we estimate virtually identical results. 
Table A2

Relationship between Live Birth Rates (Logged) and Simulated Felony Incidence Quartiles

\begin{tabular}{lcc}
\hline \hline & $(1)$ & $(2)$ \\
\hline (omitted: $1^{\text {st }}$ Quartile) & 2.5 & 1.1 \\
$2^{\text {nd }}$ Quartile Simulated Felony Incidence Dummy & $(3.7)$ & $(2.6)$ \\
& -1.5 & -1.9 \\
$3^{\text {rd }}$ Quartile Simulated Felony Incidence Dummy & $(4.2)$ & $(3.0)$ \\
$4^{\text {th }}$ Quartile Simulated Felony Incidence Dummy & $-9.8^{*}$ & $-13.6^{* *}$ \\
$\mathrm{~N}$ & $(5.4)$ & $(5.4)$ \\
State-Year Fixed & 6525 & 6525 \\
$\quad$ Effects? & NO & YES \\
Age-Year Effects? & NO & YES \\
State-Age Effects? & NO & YES \\
\hline
\end{tabular}

Notes: robust standard errors corrected for within-state correlation in the error term are reported in parentheses. Estimated coefficients and standard errors are multiplied by 100. All regressions include state, age and year fixed effects. Regressions are weighted by the female population of the associated state-year-age cell. Live birth rate data are from the Natality Detail Files.

*** Significant at the 1 percent level.

** Significant at the 5 percent level.

* Significant at the 10 percent level. 
Table A3

Additional Summary Statistics

\begin{tabular}{|c|c|c|c|c|c|c|c|}
\hline & $\begin{array}{l}\text { OVER- } \\
\text { ALL }\end{array}$ & $\begin{array}{l}12 \text { YEAR } \\
\text { OLDS }\end{array}$ & $\begin{array}{l}13 \text { YEAR } \\
\text { OLDS }\end{array}$ & $\begin{array}{l}14 \text { YEAR } \\
\text { OLDS }\end{array}$ & $\begin{array}{l}15 \text { YEAR } \\
\text { OLDS }\end{array}$ & $\begin{array}{c}16 \text { YEAR } \\
\text { OLDS }\end{array}$ & $\begin{array}{c}17 \text { YEAR } \\
\text { OLDS }\end{array}$ \\
\hline \multicolumn{8}{|c|}{ Statutory Rape Law Variables } \\
\hline $\begin{array}{l}\text { Simulated Basic Felony } \\
\text { Incidence (1-10 years } \\
\text { minimum) }\end{array}$ & $\begin{array}{c}0.44 \\
(0.41)\end{array}$ & $\begin{array}{c}0.70 \\
(0.38)\end{array}$ & $\begin{array}{c}0.66 \\
(0.33)\end{array}$ & $\begin{array}{c}(0.52) \\
0.36\end{array}$ & $\begin{array}{c}0.45 \\
(0.38)\end{array}$ & $\begin{array}{c}0.18 \\
(0.32)\end{array}$ & $\begin{array}{c}0.12 \\
(0.31)\end{array}$ \\
\hline \multicolumn{8}{|l|}{ Simulated $1^{\text {st }}$-Tier } \\
\hline $\begin{array}{l}\text { Heightened Felony } \\
\text { Incidence (10-20 years } \\
\text { minimum) }\end{array}$ & $\begin{array}{c}0.02 \\
(0.13)\end{array}$ & $\begin{array}{c}0.07 \\
(0.25)\end{array}$ & $\begin{array}{c}0.03 \\
(0.16)\end{array}$ & $\begin{array}{c}0.02 \\
(0.12)\end{array}$ & $\begin{array}{c}0.00 \\
(0.01)\end{array}$ & $\begin{array}{c}0.00 \\
(0.00)\end{array}$ & $\begin{array}{c}0.00 \\
(0.00)\end{array}$ \\
\hline \multicolumn{8}{|l|}{ Simulated $2^{\text {nd }}-$ Tier } \\
\hline $\begin{array}{l}\text { Heightened Felony } \\
\text { Incidence }(25+\text { years } \\
\text { minimum })\end{array}$ & $\begin{array}{c}0.01 \\
(0.09)\end{array}$ & $\begin{array}{l}0.04 \\
(.18)\end{array}$ & $\begin{array}{c}0.01 \\
(0.08)\end{array}$ & $\begin{array}{c}0.01 \\
(0.06)\end{array}$ & $\begin{array}{c}0.00 \\
(0.03)\end{array}$ & $\begin{array}{c}0.00 \\
(0.00)\end{array}$ & $\begin{array}{c}0.00 \\
(0.00)\end{array}$ \\
\hline $\begin{array}{l}\text { Simulated Misdemeanor } \\
\text { Incidence }\end{array}$ & $\begin{array}{c}0.09 \\
(0.23)\end{array}$ & $\begin{array}{c}0.05 \\
(0.13)\end{array}$ & $\begin{array}{c}0.07 \\
(0.18)\end{array}$ & $\begin{array}{c}0.11 \\
(0.24)\end{array}$ & $\begin{array}{c}0.12 \\
(0.27)\end{array}$ & $\begin{array}{c}0.11 \\
(0.28)\end{array}$ & $\begin{array}{c}0.08 \\
(0.24)\end{array}$ \\
\hline
\end{tabular}

Notes: data are from a sample of 6,758 state-year-age cells. The underlying data applied to the statutory rape laws of each state-year-age cell used to form the simulated statutory rape law variables are from the 1996 and 2002 arms of the National Survey of Family Growth. All measures are weighted by the associated female population of the state-year-age cell. 
Table A4

Relationship between Live Birth Rates (Logged) and Simulated Percentage of Sexual Activity that

Triggers a Crime Within Misdemeanor and Felony Punishment Tiers

\begin{tabular}{|c|c|c|c|c|}
\hline & $(1)$ & $(2)$ & (3) & $(4)$ \\
\hline \multicolumn{5}{|l|}{ Misdemeanor Incidence } \\
\hline $\begin{array}{l}\text { Simulated Percentage: 4- } \\
\text { Year Lead }\end{array}$ & - & $\begin{array}{c}-13.9 * * \\
(6.5)\end{array}$ & - & $\begin{array}{c}-13.8^{* *} \\
(6.5)\end{array}$ \\
\hline $\begin{array}{l}\text { Simulated Percentage: 2- } \\
\text { Year Lead }\end{array}$ & - & $\begin{array}{l}3.3 \\
(3.4)\end{array}$ & - & $\begin{array}{l}3.3 \\
(3.5)\end{array}$ \\
\hline Simulated Percentage & $\begin{array}{l}-6.0 \\
(6.5)\end{array}$ & $\begin{array}{l}-1.7 \\
(5.3)\end{array}$ & $\begin{array}{l}-5.8 \\
(6.2)\end{array}$ & $\begin{array}{l}-1.95 \\
(5.4)\end{array}$ \\
\hline \multicolumn{5}{|l|}{ Basic Felony Incidence } \\
\hline $\begin{array}{l}\text { Simulated Percentage: 4- } \\
\text { Year Lead }\end{array}$ & - & $\begin{array}{c}0.5 \\
(5.4)\end{array}$ & - & $\begin{array}{c}0.6 \\
(5.5)\end{array}$ \\
\hline $\begin{array}{l}\text { Simulated Percentage: 2- } \\
\text { Year Lead }\end{array}$ & - & $\begin{array}{c}0.5 \\
(4.6)\end{array}$ & - & $\begin{array}{c}1.3 \\
(4.8)\end{array}$ \\
\hline Simulated Percentage & $\begin{array}{c}-14.1 * * \\
(5.7)\end{array}$ & $\begin{array}{c}-14.1^{* *} \\
(6.3)\end{array}$ & $\begin{array}{c}-14.4 * * * \\
(5.3)\end{array}$ & $\begin{array}{c}-14.8^{* *} \\
(6.1)\end{array}$ \\
\hline \multicolumn{5}{|c|}{$\underline{1}^{\text {st }}$ Tier Heightened Felony Incidence } \\
\hline $\begin{array}{l}\text { Simulated Percentage: 4- } \\
\text { Year Lead }\end{array}$ & - & $\begin{array}{l}-5.3 \\
(10.0)\end{array}$ & - & $\begin{array}{l}-10.1 \\
(11.8)\end{array}$ \\
\hline $\begin{array}{l}\text { Simulated Percentage: 2- } \\
\text { Year Lead }\end{array}$ & - & $\begin{array}{c}7.6 \\
(14.6)\end{array}$ & - & $\begin{array}{l}19.3 \\
(9.8)\end{array}$ \\
\hline Simulated Percentage & $\begin{array}{l}-1.7 \\
(8.2)\end{array}$ & $\begin{array}{l}-5.4 \\
(11.1)\end{array}$ & $\begin{array}{c}0.6 \\
(8.9)\end{array}$ & $\begin{array}{l}-8.3 \\
(9.2)\end{array}$ \\
\hline \multicolumn{5}{|l|}{$2^{\text {nd }}-$ Tier Heightened Felony } \\
\hline \multicolumn{5}{|l|}{ Incidence } \\
\hline $\begin{array}{l}\text { Simulated Percentage: 4- } \\
\text { Year Lead }\end{array}$ & - & - & - & $\begin{array}{l}-3.3 \\
(12.8)\end{array}$ \\
\hline $\begin{array}{l}\text { Simulated Percentage: 2- } \\
\text { Year Lead }\end{array}$ & - & - & - & $\begin{array}{c}0.5 \\
(23.4)\end{array}$ \\
\hline Simulated Percentage & - & - & $\begin{array}{l}-8.3 \\
(9.4)\end{array}$ & $\begin{array}{c}-6.9 \\
(18.8)\end{array}$ \\
\hline $\mathrm{N}$ & 6521 & 6521 & 6521 & 6521 \\
\hline
\end{tabular}

Notes: robust standard errors corrected for within-state correlation in the error term are reported in parentheses. Estimated coefficients and standard errors are multiplied by 100. All regressions include state, age and year fixed effects, along with state-year effects, age-year effects and state-age effects. Regressions are weighted by the female population of the associated state-year-age cell. Live birth rate data are from the Natality Detail Files.

*** Significant at the 1 percent level.

** Significant at the 5 percent level.

* Significant at the 10 percent level. 
Table A5

Relationship between Live Birth Rates (Logged) and Simulated Percentage of Sexual Activity

that Triggers a Felony: Poisson Regression Results

(1)

(2)

(3)

(4)

(5)

(6)

(7)

Panel A. Poisson Regression Coefficients

Simulated Felony

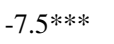

$-7.5 * * *$

$-8.4 * * *$

$-8.4^{*}$

$-4.4$

$-4.1$

$-2.0$

Percentage

(2.6)

(2.6)

(3.0)

(4.6)

(5.5)

(5.2)

Percentage Black

-

-

$125.6 *$

(42.8)

Panel B. Incidence-Rate Ratios for Contemporaneous Simulated Felony Percentage Variable

\begin{tabular}{|c|c|c|c|c|c|c|c|}
\hline IRR & 0.93 & 0.93 & 0.92 & 0.92 & 0.96 & 0.96 & 0.98 \\
\hline $\mathrm{N}$ & 6525 & 6437 & 6525 & 6525 & 6525 & 6437 & 6525 \\
\hline $\begin{array}{l}\text { State-Year } \\
\text { Covariates }\end{array}$ & $\mathrm{NO}$ & YES & $\mathrm{NO}$ & $\mathrm{NO}$ & $\mathrm{NO}$ & $\mathrm{NO}$ & $\mathrm{NO}$ \\
\hline $\begin{array}{l}\text { State-Year Fixed } \\
\quad \text { Effects? }\end{array}$ & NO & NO & YES & YES & YES & YES & YES \\
\hline Age-Year Effects? & $\mathrm{NO}$ & $\mathrm{NO}$ & $\mathrm{NO}$ & $\mathrm{NO}$ & YES & YES & YES \\
\hline State-Age Effects? & $\mathrm{NO}$ & $\mathrm{NO}$ & NO & $\mathrm{NO}$ & YES & YES & YES \\
\hline $\begin{array}{l}\text { State-Age-Specific } \\
\text { Linear Time Trends }\end{array}$ & $\mathrm{NO}$ & NO & $\mathrm{NO}$ & YES & NO & NO & YES \\
\hline
\end{tabular}

Notes: robust standard errors corrected for within-state correlation in the error term are reported in parentheses. Estimated coefficients and standard errors are multiplied by 100 . All regressions include state, age and year fixed effects. Poisson regressions include an offset equal to the $\log$ of the female population of the associated state-year-age cell. Live birth rate data are from the Natality Detail Files. . *** Significant at the 1 percent level.

** Significant at the 5 percent level.

* Significant at the 10 percent level. 
Table A6

Falsification Exercise: Relationship between 18-20 Year-Old Live Birth Rates (Logged) and Simulated Percentage of Sexual Activity Among 12-17 Year Olds Triggering a Felony

\begin{tabular}{lccc}
\hline & $(1)$ & $(2)$ & $(3)$ \\
\hline & 18-Year Olds & 19-Year Olds & 20-Year Olds \\
Simulated Felony Percentage & 7.8 & 5.7 & 6.2 \\
$\mathrm{~N}$ & $(5.5)$ & $(5.1)$ & $(5.2)$ \\
\hline
\end{tabular}

Notes: robust standard errors corrected for within-state correlation in the error term are reported in parentheses. Estimated coefficients and standard errors are multiplied by 100. All regressions include state, age and year fixed effects. The simulated felony percentage variable captures the percentage of sexual activity among 12-17 year olds that triggers a felony within the operable state-year cell. Live birth rate data are from the Natality Detail Files. .

*** Significant at the 1 percent level.

** Significant at the 5 percent level.

* Significant at the 10 percent level. 
Table A7

Relationship between Race-Specific Live Birth Rates (Logged) and Simulated Percentage of Sexual Activity Triggering a Felony

\begin{tabular}{|c|c|c|c|}
\hline & $(1)$ & $(2)$ & (3) \\
\hline & White Females & Black Females & $\begin{array}{c}\text { Other-Race } \\
\text { Females }\end{array}$ \\
\hline Simulated Felony Percentage & $\begin{array}{l}-2.9 \\
(7.0)\end{array}$ & $\begin{array}{c}-12.9 * \\
(7.4)\end{array}$ & $\begin{array}{c}-13.0 \\
(21.10)\end{array}$ \\
\hline $\mathrm{N}$ & 6525 & 6525 & 6525 \\
\hline
\end{tabular}

Notes: robust standard errors corrected for within-state correlation in the error term are reported in parentheses. Estimated coefficients and standard errors are multiplied by 100 . All regressions include state, age and year fixed effects, along with state-year, state-age and age-year fixed effects. Regressions are weighted by the female population of the associated state-year-age cell (of the relevant race). Live birth rate data are from the Natality Detail Files. .

*** Significant at the 1 percent level.

** Significant at the 5 percent level.

* Significant at the 10 percent level. 
Table A8

Relationship between Abortion Rates (Logged) and Simulated Percentage of Sexual Activity that Triggers a Felony (Ages 13-17, 1991-2004, 46 Reporting States)

\begin{tabular}{lcccc}
\hline & $(1)$ & $(2)$ & $(3)$ & $(5)$ \\
\hline Simulated Felony Percentage & $-14.8^{*}$ & $-14.4^{*}$ & $-15.5^{*}$ & 15.9 \\
$\mathrm{~N}$ & $(8.1)$ & $(8.0)$ & $(8.4)$ & $(19.2)$ \\
State-Year Covariates & 2263 & 2263 & 2263 & 2263 \\
State-Year Fixed Effects? & NO & YES & NO & NO \\
Age-Year Effects? & NO & NO & YES & YES \\
State-Age Effects? & NO & NO & NO & YES \\
\hline
\end{tabular}

Notes: robust standard errors corrected for within-state correlation in the error term are reported in parentheses. Estimated coefficients and standard errors are multiplied by 100 . The dependent variable in the above specifications is the natural $\log$ of the relevant abortion rate. All regressions include state, age and year fixed effects. Given the nature of the collected abortion data, the 13 and 14 year-old groups are consolidated into one age group, whereas the 15-17 year-old groups are individually represented in the specifications. Data are from 46 reporting states, excluding California, Florida, Illinois, Maryland, New Hampshire, and Rhode Island, which either did not report, did not report age among adolescents by individual year, or did not meet reporting standards for age. Abortion data are from the Centers for Disease Control.

*** Significant at the 1 percent level.

** Significant at the 5 percent level.

* Significant at the 10 percent level. 